\title{
Geology of the Southern Half of the Millerstown, Pennsylvania 15 Minute Topographic Quadrangle
}

\author{
George Calvert Robinson \\ West Virginia University
}

Follow this and additional works at: https://researchrepository.wvu.edu/etd

Part of the Geology Commons

\section{Recommended Citation \\ Robinson, George Calvert, "Geology of the Southern Half of the Millerstown, Pennsylvania 15 Minute Topographic Quadrangle" (1957). Graduate Theses, Dissertations, and Problem Reports. 10149. https://researchrepository.wvu.edu/etd/10149}

This Thesis is protected by copyright and/or related rights. It has been brought to you by the The Research Repository @ WVU with permission from the rights-holder(s). You are free to use this Thesis in any way that is permitted by the copyright and related rights legislation that applies to your use. For other uses you must obtain permission from the rights-holder(s) directly, unless additional rights are indicated by a Creative Commons license in the record and/ or on the work itself. This Thesis has been accepted for inclusion in WVU Graduate Theses, Dissertations, and Problem Reports collection by an authorized administrator of The Research Repository @ WVU. For more information, please contact researchrepository@mail.wvu.edu. 
GEOLOGY OF THE SOUTHERN HALW OF THE MCLLERSTOWN, PENANSTLVANIA 15 MINUTE TOPOGRAPHIC QUADRANGLE

\title{
Theris
}

Submitted In Partial Fulfillment of the Requirements for the Degree of Master of Selence

in the

\section{Faculty of the Graduste Sehool. of}

West Virginia University

\section{by}

\author{
George C. Robinson, B.S. \\ Morgantown \\ West Virginia \\ 1957
}


w

$$
\begin{aligned}
& 378.7543 \\
& 600 . \\
& R 5629 \\
& C .3
\end{aligned}
$$

$$
\begin{gathered}
\text { Library } \\
\text { West Virginia University }
\end{gathered}
$$




\section{ACKAOWLEDGEMENTS}

The preparation of this thesis has been made possible by the willing assistance and co-operation of many individuals. The author is deeply grateful to Dr. John C. Ludlum who served as head nf the advisory committee. Thanks also are due Dr. Harry M. Fridley and Dr. Dana Wells for valuable suggestions and criticisws whlch aided in the writing of this report.

The writer is Indebted to Dr. Carlyle Gray, State Geologlist of Penngylvania, for contributing suggestions, and for the lom of Pennsylvania Geological Survey publications and aeriml photographs. Mr. John T. Miller of the Pennsylvania Geological Survey aided the writer in the fleld and was a valuable source of informotion on stratigraphy of the area.

The writer acknowledges his indebtedress to the author: of previous reports and publications which served ss sources of Information on the area investigated.

To my wife, Gwen, I wish to express my appreciation for assistance in coloring the geologic ans, and editing and typing the original mamuscript. 


\section{ABSTRACT}

A detalled investigation of the geology of the southern aewhalf of the Millerstown, Pennsylvania 15 Minute Topographic Quadrangle was conducted during 1956-1957. This report of the work contains a description of the Silurian, Devonian, and Mississippian formations which crop out in the area. The complex folding and faulting of the sediments is outlined in a section on structural geology. A number of anticlines and synclines, not previously mapped, are described.

A geologic map and two structural cross sections with a scale of 1:24000 are included to 111ustrate the features described. This is the first geologic map of the area on a topographic base. A short discussion of drainage patterns and alignment of gaps is also included. Past utilization of the natural resources of the area and possible future development is discussed in a section on economic geology. 
PAGE

ACKTOWLEDGEMENTS ..................

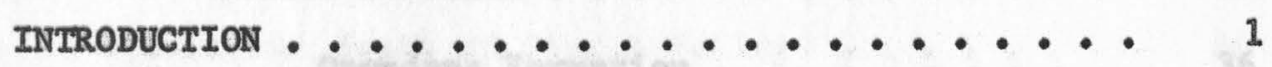

Puxpose and Methods of Investigation ..... 2

Previous Geologic Work .......... 3

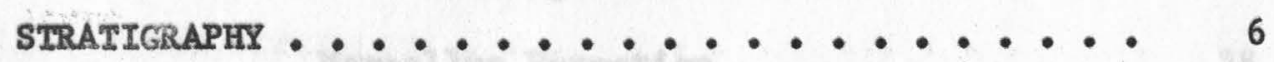

silurian System ............. 8

Medinan Series ........... 10

Niagaran Serwes ........... 14

Rose Hill Formation ....... 14

Keefer Formation ........ 17

Molkenale Formation . . . . . . 19

Cayugan Series ............ 21

Bloomsburg Formation ........ 21

Wills Creek Formation ....... 23

Tonoloway Formation ....... 25

Keyser Formation ......... 26

Devonian System ... . . . . . . . . 29

Lower Devonian .......... . 29

Helderberg Group ......... 31

Coeymans Limestone ....... 31

New Scotland Limestone .... 32

Mandata Shale ......... 33 
Oriskany Group ........ 34

Shriver Chert ........ 34

Ridgeley Sandstone ..... 35

Middle Devonian ........... 36

Onondaga Formation ........ 36

Needmore Shale ....... 36

Selinsgrove Limestone ..... 37

Marcellus Formation ....... 38

Hamilton Formation ....... 41

Montebello Sandstone ..... 41

Mahantango Shale ...... 43

Upper Devonian ......... 44

Portage Group ......... 44

Tully Limestone ....... 45

Burkett Shale and Harrell Shale 45

Brallier Shale and Trimmers Rock

Sandstone ....... 46

Chemung Formation ........ 48

Catskill Formation ........ 49

Mississippian System ............ 51

Pocono Formation ......... 51

Mauch Chunk Formation ........ 54

STRUCTURAL GEOLOGY ................. 56

Millersburg Syncline . ........ 59

Tuscarora Anticline .......... 61 
Tuscarora Syncline ..............

Academia Anticline .......... 63

East Salem Syncline ............ 64

Structures North of Pfoutz Valley . . . . . 64

Dalmatia Anticline ........... 65

Faults ............ 66

Shear Fractures . . . . . 69

Joints ............. 70

Slickensides ............ 72

GEOMORPHOLOGY ................... 73

Topography ............. 73

Drainage ............ 74

Wind Gaps ........... 75

Water Gaps .......... 76

Stream Piracy ............. 78

Future Capture of the Susquehanna . . . . 79

ECONOMIC GEOLOGY ................ 81

Agricultural limestone ........ 81

Building Stone ........... 82

Ceramic Material .......... 82

Ganister ............... 83

Iron ore .................. 83

Road Material ... . . . . . . 85

Soil .................. 86

Water .............. 87 


\section{PAGE}

CONCLUSIONS ............................ 89 APPENDIX ............. (Envelope on Back Cover)

Areal Geologic Map

Cross Sections

BIBLIOGRAPHY ........................ 90

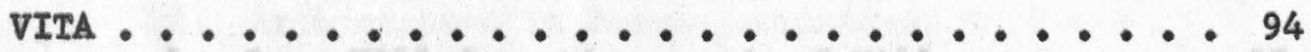

APPROVAL OF EXAMINING COMMITTEE .......... 95 


\section{LIST OF FIGURES}

1. Map showing area of investigation ..... 5

2. Subdivisions of the Silurian System in southcentral Pennsylvania .......... 9

3. Tuscarora sandstone and shale along highway one mile north of Millerstown. ....... 11

4. Tuscarora float blocks on Slaughterback Hi11. ............. 13

5. Rose Hill formation north of Millerstown . 15

6. Ledge of ferruginous Rose Hill sandstone in Slaughterback Hill ........... 16

7. McKenzie shales with interbedded limestone - 20

8. Wills Creek shale near Donnally Mills ... 24

9. Tonoloway Iimestone near East Salem . . . 26

10. Quarry in Tonoloway and Keyser limestone . 27

11. Subdivisions of Mississippian Devonian Systems in south-central Pennsylvania...

12. Shriver chert five miles north of Liverpool ................

13. Mahanoy upper black shale member of the Marcellus formation esposed in gap south of Donnally Mills ..........

14. Montebello sandstone exposed in gap south of Donnally Mills ...........

15. Buxket-Harrell shales exposed one mile south of Millerstown ..........

16. Trimmers Rock sandstone exposed two miles north of Seven Stars ..........

17. Rol1-bottom sandstone in Catskil1 formation one mile north of the Newport bridge . . . 


\section{IIST OF FIGURES (CONTINUED)}

FIGURE

PAGE

18. Weathered surface of Pocono quartz-pebble conglomerate ............... .

19. Impure coal and carbonaceous shale near top of Pocono formation ........... 53

20. Brick-red Mauch Chunk shale one mile west of Mt. Patrick . . . . . . . . . . .

21. Siderite concretions in Mauch Chunk formation near Mount Union

22. Arch exposed in Pocono sandstone, east end of Buffalo Mountain .............

23. Tuscarora sandstone exposed in south flank of Tuscarora Mountain ................

24. Arch exposed along road one mile north of Wardvilie....................

25. Exposed fault a half mile north of Thompson-

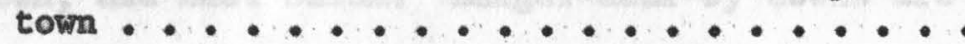

26. Exposed fault surface just north of that shown in Figure $25 \ldots \ldots \ldots \ldots$

27. Exposed fauli a half mile north of Ward-

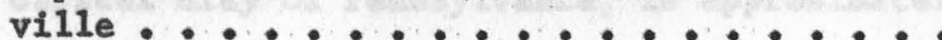

28. Faulted sandstone and shales in east end of Berry Mountain .............

29. Shear fracture developed in shale adjacent to fault surface............. 70

30. Block-jointing in Hamilton sandstone ... 71

31. We11 developed joint planes in Marcellus shale.

32. Slickensides formed on fault surface in a block of hamilton sandstone .........

33. Diagram illustrating wind and vater gaps in Berry and Buffalo Mountains ....... 
The Millerstown quadrangle is located in south central Pennsylvania, and includes portions of northeastern Perry County, western Juniata County, and south central Snyder County.

The quadrangle is between the longitudes $77^{\circ} 00^{\prime}$ and $77^{\circ} 15^{\circ}$ $W$ and the latitudes $40^{\circ} 30^{\prime}$ and $40^{\circ} 45^{\circ} \mathrm{N}$. It is bounded on the north by the Mifflinburg quadrangle, on the east by the Millersburg quadrangle, on the south by the New Bloomfield quadrangle, and on the west by the Mifflintown quadrangle. Only the southern half of the quadrangle was studied in preparation of this report (Figure 1). There are only three communities of appreciable size in the area mapped. They are in order of decreasing size, Millerstown, Thompsontown, and East Salem. Larger near-by towns are Liverpool and Millersburg,just east of the Millerstown quadrangle, and Newport which is on the Juniata River six miles south of Millerstown. Harrisburg, the capital city of Pennsylvania, is approximztely thirty miles south of the Millerstown quadrangle.

The area is accessible by U. S. Routes 11 and 15 which pass by Liverpool and U. S. Routes 22 and 322 which follow the Juniata River past Millerstown and Thompsontown. Numerous state, county, and township roads of good quality checkerboard the area, leaving no places isolated other than the higher ridges.

This area contains, within Perry County, portions of the townships Tuscarora, Juniata, 0liver, Howe, Buffalo, Liverpool, and Greenwood. In Juniata County portions of the townships of Delaware, Greenwood, and Susquahanna are included. The area mapped constitutes 
the southern half of a standard U.S.G.S. $15^{\prime}$ quadrangle. It is approximately 13.15 miles wide east-west, 8.65 miles north-south, and comprises 114 square miles. The area 1 s wholly within the Valley and Ridge province of the Appalachian region. It is noteworthy that it is in the widest portion of the Valley and Ridge province, and the structural trend is in a nearly east-west direction rather than the usual northeast-southwest.

\section{Purposes and Methods of Investigation}

This Investigation was undertaken primarily to construct an improved geologic map of the southern half of the Millerstown quadrangle, and to make a study of the structural,stratigraphic and economic aspects of the area. Field work was conducted during the summer of 1956, one week in November 1956, and one week in June 1957.

The maps used were U.S.G.S. $15^{\prime}$ topographic maps of the Millerstown and surrounding quadrangles. Both the 1905 and the 1943 editions of the Millerstown quadrangle were used. U.S.G.S. $7.1 / 2^{\prime}$ quadrangles of the western half of the Millersburg and Harrisburg $15^{\prime}$ quadrangles were also used, but maps of this scale have not been completed for the area under investigation. Another map found useful was the U. S. Harrisburg 1950 edition prepared by the U. S. Corps of Engineers, with a seale of $1: 250,000$. Photostatic copies of the Millerstown $15^{\prime}$ quadrangle, 1943 edition, with a scale of 1:62,500, were enlarged to a scale of 
I:24,000. This is the scale of the more modern $712^{\prime}$ maps being produced by the U.S.G.S. These photostats do not have the accuracy of the standard 1:24,000 maps, as the maps from which they were made were not prepared by the more modern photo-planimetric methods. Also a certain amount of distortion is induced in developing the photostatic copies due to shrinkage of the paper.

Aerial photographs with a scale of $1: 20,000$ were very helpful in plotting locations of outcrops on the map. The photos also were useful in following contacts where the change in color of the sol1 or vegetation was noticeable. The topographic expression of more resistant beds was easily followed on the photographs when viewed with the stereoscope.

\section{Previous Geologic Work}

The first geologic map of Pennsylvania was published in 1858 by Henry D. Rogers of the Pennsylvania First Geological Survey. The area under investigation was later mapped by the Pennsylvania Second Geological Survey, on a scale of two miles to the inch, before a topographic map had been produced. The base or working map was made from county road maps and maps of the Pennsylvania Railroad rights of way.

The section within Perry County is described in a report on that county (Claypole, 1885). This report contains a geologic map prepared by J. P. Lesley in 1878, and a revised edition by Claypole published in 1883. A report covering that part of the area within Juniata County was described by E. V. d'Invilliers (1891). 
Included with this report was a geologic map of Juniata and Smyder Counties published by d'Invilliers in 1888. Bradford Willard, F。 M. Swartz, and Arthur B. Cleaves published a report on the Devonian of Pennsylvanis in 1939, which contains some references to the area. Material from previous publications on Devonian strata by Bradford Willard are included in that report. Other publications with reference to the area of this report are those of the Pennsylvania Geologieal Survey Fourth Series. This series contains reports on limestones, shales, building stones, silica refractories, and ground water. At the time of this writing, geologic mapping is being conducted by the Pennsylvania Survey in nearby quadrangles. Mr. Richard Conlin is mapping the Mifflintown quadrangle to the west. The Loysville quadrangle to the southwsst is being mapped by Mr. John T. Miller who plans also to make a study of the Millersburg quadrangle, which lies to the east. Dr. James L. Dyson is continuing his study of the New Bloomsfield quadrangle, just south of the Miller:town quadrangle. 


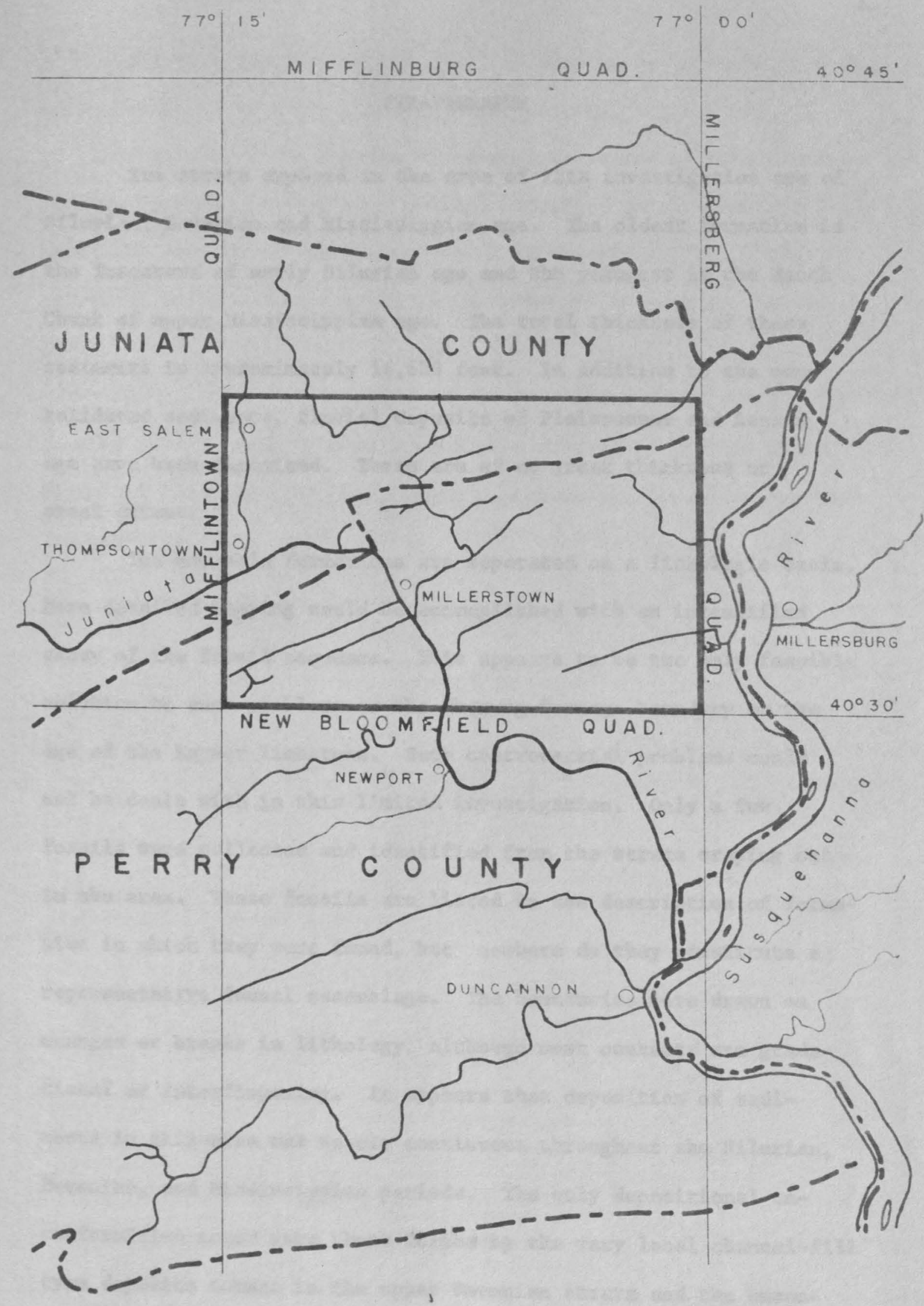

Map Showing Area of Investigation Figure $\quad$ 


\section{STRATIGRAPHY}

The strata exposed in the area of this investigation are of Silurian, Devonian and Mississippian age. The oldest formation is the Tuscarora of early Silurian age and the youngest is the Mauch Chunk of upper Mississippian age. The total thickness of these sediments is approximately 16,600 feet. In addition to the conssolidated sediments, fluvial deposits of Pleistocene and Recent age have been deposited. The se are of no great thickness or areal extent.

The mappable formations are separated on a lithologic basis. Hore detailed mapping could be accomplished with an intensified study of the fossil sequence. This appears to be the only feasible solution to such problems as the Chemung-Portage boundary or the age of the Keyser limestone. Such controversial problems could not be dealt with in this limited investigation. Only a few fossils were collected and identified from the strata croping out in the area. These fossils are listed in the description of formation in which they were found, but nowhere do they constitute a representative faunal assemblage. The boundaries were drawn on changes or breaks in lithology, although most contacts are gradational or interfingering. It appears that deposition of sediments in this area was nearly continuous throughout the Silurian, Devonian, and Mississippian periods. The only depositional unconformities noted were those formed by the very local channel-fill type deposits common in the upper Devonian strata and the uncon- 
Alluvial deposits of two ages are present in the area. South of Turkey Ridge in the vicinity of Thompsontown, a thick deposit of alluvium covers the surface. The unconsolidated material varies in texture from clay to large rounded bolders. This terrace is about 100 feet above the present level of the river. It is described as an Illinoian fluvial plain by Frank Leverett (pp. 48-49, 1934).

Recent alluvial deposits may be seen along the streams flowing in the area. The only extensive deposit is the low plain along the south bank of the Juniata approximately two miles east of Thompsantown. 
Outcropping strata of Silurian age comprise a thickness of about 3340 feet in the area of this investigation. This is approsimately the total thickness of the Silurian system present, as only a few feet of the lowermost beds are not exposed.

In this area silurian strata crop out in three places. The largest outcrop belt of Silurian age is along this axis of the Tuscarora anticline. Here the Silurian rocks occupy that interval between Turkey Ridge on the north, and Raccoon and Wildeat Ridges on the south. This belt extends from the western border nearly to the eastern border of the map.

The next major fold north of the Tuscarora anticline has been eroded so as to expose Silurian strata at the surface. This Is the east plunge area of the Academia anticline which shows upper Silurian strata along the western boundary of the map approsimately halfway between Thompsontown and East Salem.

North of East Salem an extension of the Blacklog Mountain anticline has the uppermost silurian rocks along its axis.

The Silurian system has been subdivided as follows:

Cayugan series

Keyser formation Tonoloway formation Wills Creek formation Bloomsburg formation

Niagaran series McKenzie formation Rochester formation Keefer formation Rose Hill formation 


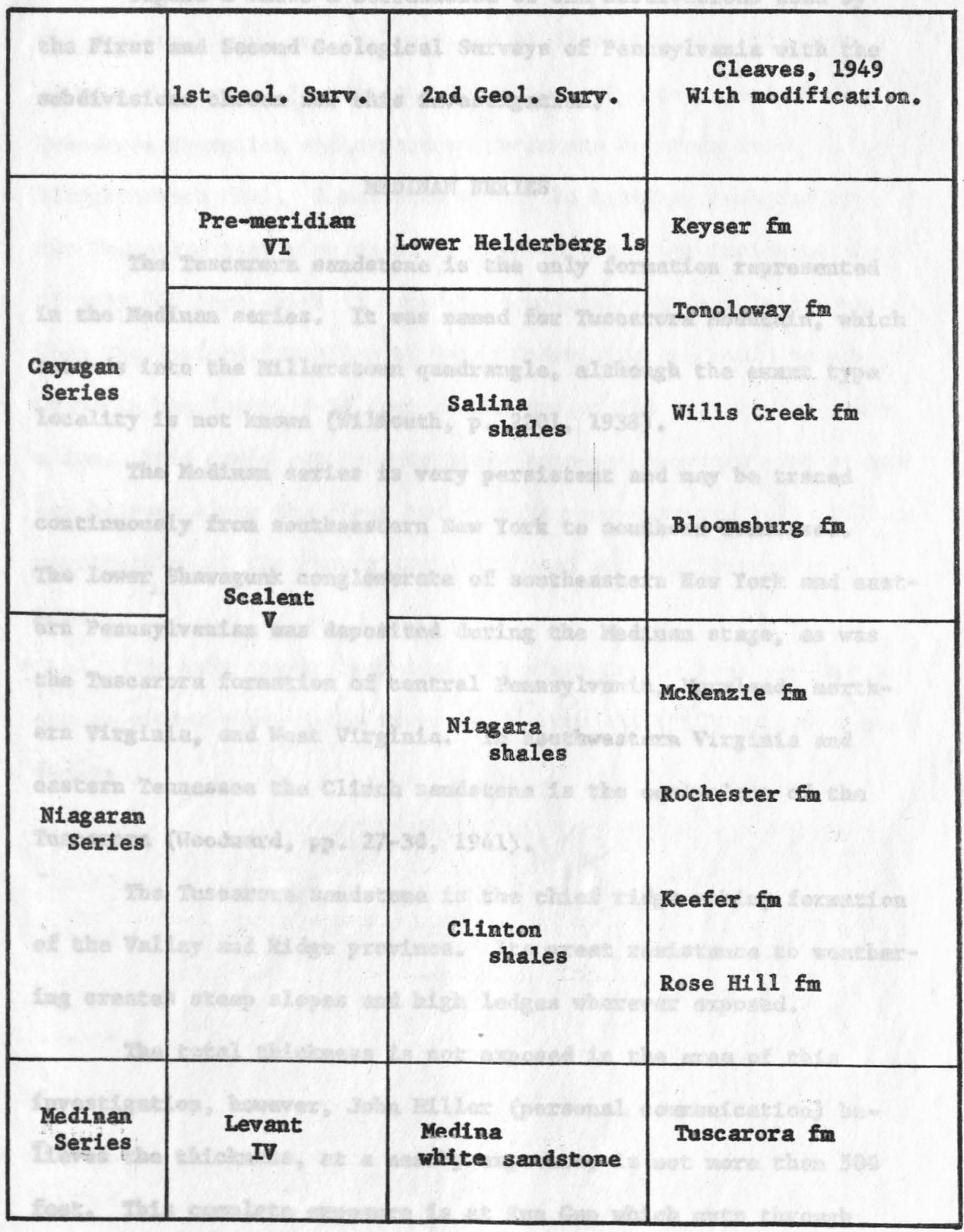

Fig. 2. Subdivisions of the Silurian System in south-central Pennsylvania. 
Figure 2 shows a correlation of the subdivisions used by the First and Second Geological Surveys of Pemsylvania with the subdivisions chosen for this investigation.

\section{MEDINAN SERIES}

The Tuscarora sandstone is the only formation represented In the Medinan series. It was named for Tuscarora Mountain, which extends into the Millerstown quadrangle, although the exaxt type locality is not known (Wileouth, p. 2201, 1938).

The Medinan series is very persistent and may be traced continuously from southeastern New York to southern Tennessee. The Lower Shawagunk conglomerate of southeastern New York and eastern Pennsylvanian was deposited during the Medinan stage, as was the Tuscarora formation of central Pennsylvania, Maryland, northern Virginia, and West Virginia. In southwestern Virginia and eastern Tennessee the Clinch sandstone is the equivalent of the Tuscarora (Woodward, pp. 27-30, 1941).

The Tuscarora sandstone is the chief ridge making formation of the Valley and Ridge province. Its great resistance to weathering creates steep slopes and high ledges wherever exposed.

The total thickness is not exposed in the area of this Investigation, however, John Miller (personal communication) beIieves the thickness, at a nearby exposure, is not more than 500 feet. This complete exposure is at Run Gap which cuts through Tuscarora Mountain about fourteen miles west of Millerstown. 
The outcrop area is limited to Tusearora Mountain west of the Juniata River, and the west end of Slaughterback Hill just across the river. The Juniata River has cut a deep gap into the Tuscarora formation and separated Tuscarora Mountain from Slaughterback Hill. A measurement of the interval occupied by the Tuscarora formation where it crosses the river indicates that if only 500 feet thick it would be completely exposed in the gap. Thus the Juniata formation of Upper Ordovician age would be exposed in the lower 30-50 feet of the gap at the axis of the anticline. This could not be determined because no outcropping strata can be seen along the river banks as they were covered with fill in construction of the Pennsylvania Railroad and the Pennsylvania Canal.

The only strata definitely in place in the area are in the gap on either side of the river well above the railroad and camal fills.

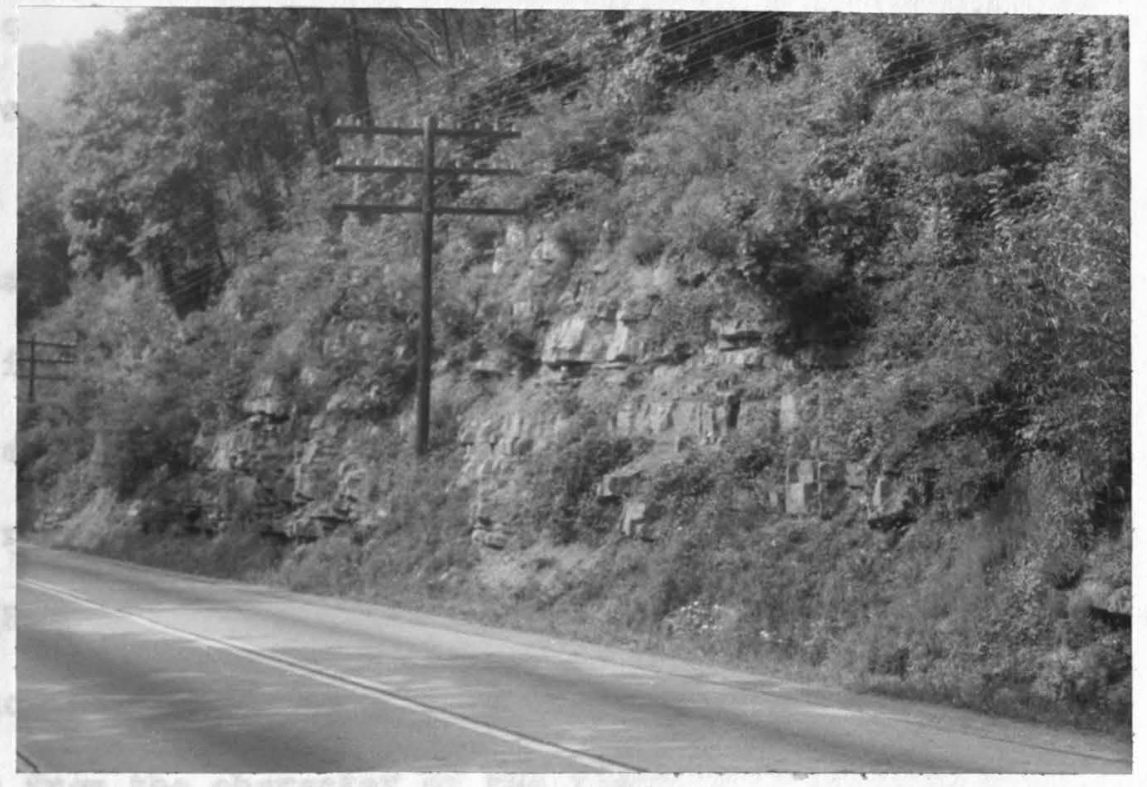

Fig. 3. Tuscarora sandstone and shale along highway one mile north of Millerstown. 
The character of the Tuscarora formation, exposed along the highway one mile north of Millerstown, is a medium to massive bedded andstone containing a few thin to medium beds of shale. The total thickness exposed there is about thirty feet. The sandstone is hard, dense, grayish white, medium-grained and faintly cross-bedded. On the weathered surface it has a pale yellowish brown or reddish brown color. Jointsets intersecting nearly at right angles give the outcrop a very sharp angular face. The sandstone beds are occasionally separated by a thin layer of grayish-green relatively soft shale. The shales range from one inch up to one foot in thickness. No fossils were found at this exposure (Fig ure 3).

On the hillside about 100 feet above the highway and 300 feet south of the section just described, about 15 feet of the Tuscarora formation is exposed. It is thick-bedded, white, graywhite and pink, strongly cross-bedded, extremely hard and dense, siliceous quartz sandstone. This is in fact a subquartzite as ft fractures through the quartz grains rather than around them. It appears to be almost pure silica although the red brown color of some weathered surfaces indicates the presence of a small amount of iron. The quartz grains are sub-rounded and of medium to coarse sand size. The rock is coarsely block-jointed giving rise to a thick layer of loose float rock covering the hillside (Figure 4). These very resistant blocks of subquartzite and sandstone are both above and below the bed rock exposure. It appears from the character of the float that the upper 400 feet of the Tuscarora formation is largely comprised of subquartzite. 
Some of the float rock is a conglomerate containing small we11rounded white quartz pebbles up to 0.2 inches in diameter. Arthrophycus alleghaniensis (Hanlan) was found in subquartzite and sandstone float blocks covering the hillside. Scolithus verticalis Hall, was found in float blocks and in the bed rock subquartzite. No other definite fossil remains were found, although impressions were found in a fragment of Tuscarora sandstone float which may be either fossils or clay galls.

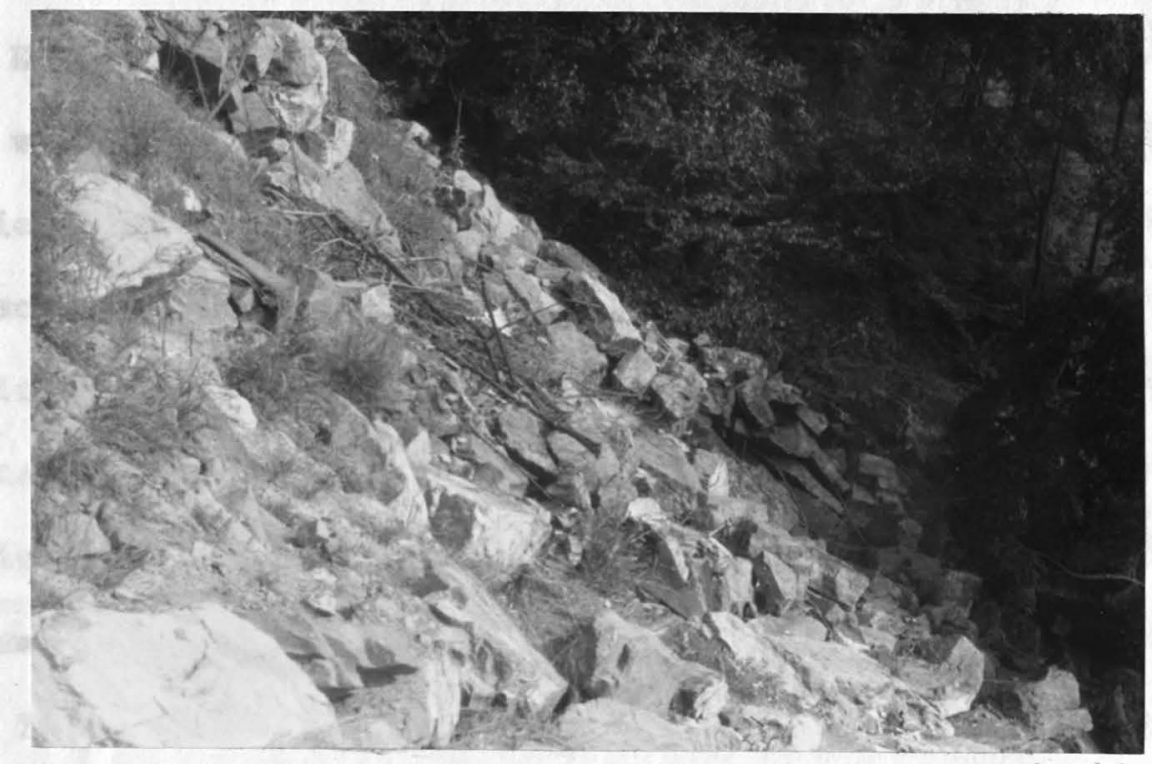

Fig. 4. Slope covered with Tuscarora float. Slaughterback Hill near axis of Tuscarora anticline one mile north of Millerstown.

The top and bottom contacts of the Tuscarora formation are not exposed in the area. Near Harrisburg the Tuscarora grades transitionally without sharp contacts downward into the red sandstones of the Juniata formation, and upward into the red and gray sandstones of the Rose Hill formation (Willard, P. 3, 1948). 


\section{NIAGARAN SERIES}

The Niagaran series is subdivided into the McKenzie, Rose Hi11, Keefer, and Rochester formations. The total thickness of the series is estimated as 860 feet.

\section{ROSE HIIL FORMATTON}

The Rose Hill formation was named by C. K. Swartz (1923, p. 28) for Rose Hill in Cumberland, Maryland. The formation includes the strata between the top of the Tuscarora and the base of the Keefer sandstone. In the area investigated the formation is not well exposed, but the interval occupied by the Rose Hill formation in Slaughterback Hill, along the Juniata River north of the Tuscarora anticline axis, is about 700 feet thick. The Rose Hill formation crops out only in Slaughterback Hill and along the flanks of Tuscarora Mountain. The resistant float rock of the Tuscarora formation has covered the Rose Hill along Tuscarora Mountain but the formation is exposed in scattered places on Slaughterback Hill. The Rose Hill consists largely of olive-green and purplish, thin-bedded, argillaceous, ferruginous, shales and siltstones. These are interbedded with thin- to medium-bedded, gray to tan, argillaceous quartz sandstones, and thin- to thick-bedded deeppurple highly ferruginous quartz sandstone (Figures 5 and 6).

The massive thick-bedded ferruginous sandstone units are near the top and also just above the middle of the formation. They are associated with other thinner beds of purplish sandstone and interbedded shales. A few of these thin iron-rich beds, which have 


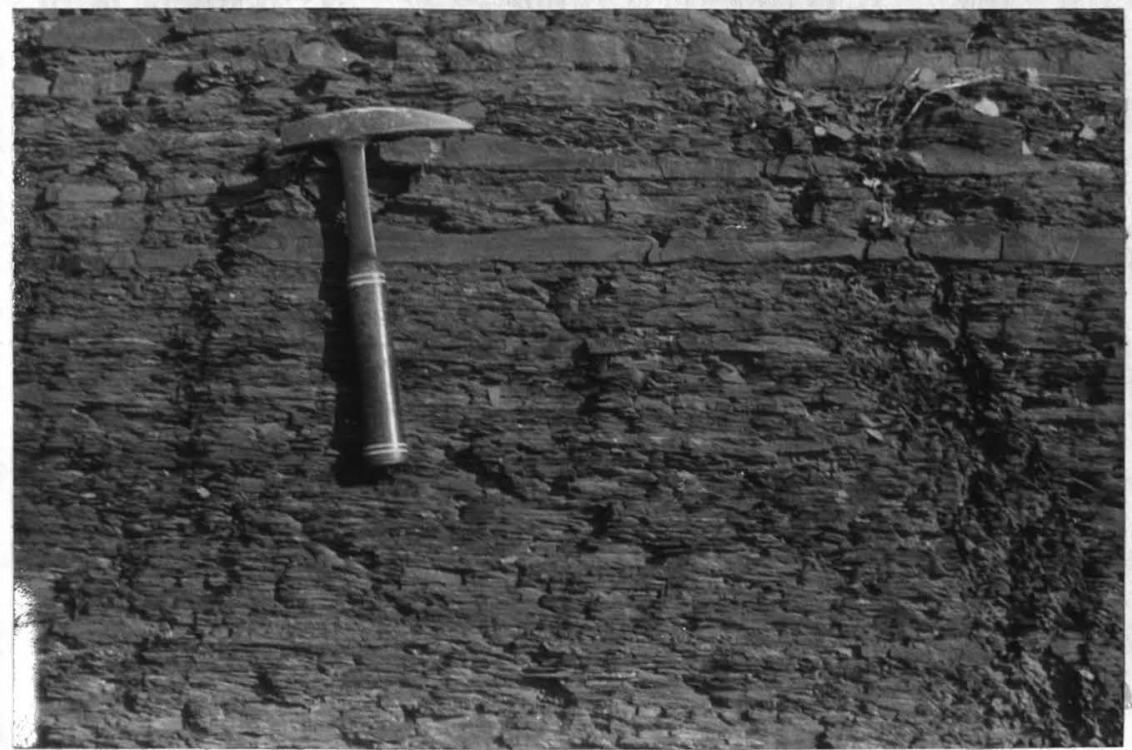

Fig. 5. Thin-bedded sandstones and shales of Rose Hill formation. Two miles north of Millerstown.

been partly leached of silica, were once exploited for iron ore In the area. This is further discussed in the section on economic geology. The upper iron sandstone occupies the position of a similar Iron sandstone within the Rose Hill formation near Cumberland, Maryland. There it is known as the Cresaptown Iron Sandstone (C. K. Swartz, p. 29, 1923).

One mile south of Wardville the upper layer of hard dense ferruginous sandstone crops out along the east end of Slaughterback Hi11. The sandstone is 20 feet thick and dips $15^{\circ} \mathrm{SE}$. Above this bed and below the Reefer sandstone is a covered zone 120 feet thick. Float rock indicated it is an olive-green fossiliferous shale containing sandstone and thin beds of oolitic hematite. This non-resistant unit has been mapped with the Keefer sandstone although it may be largely of Rose Hill age. 


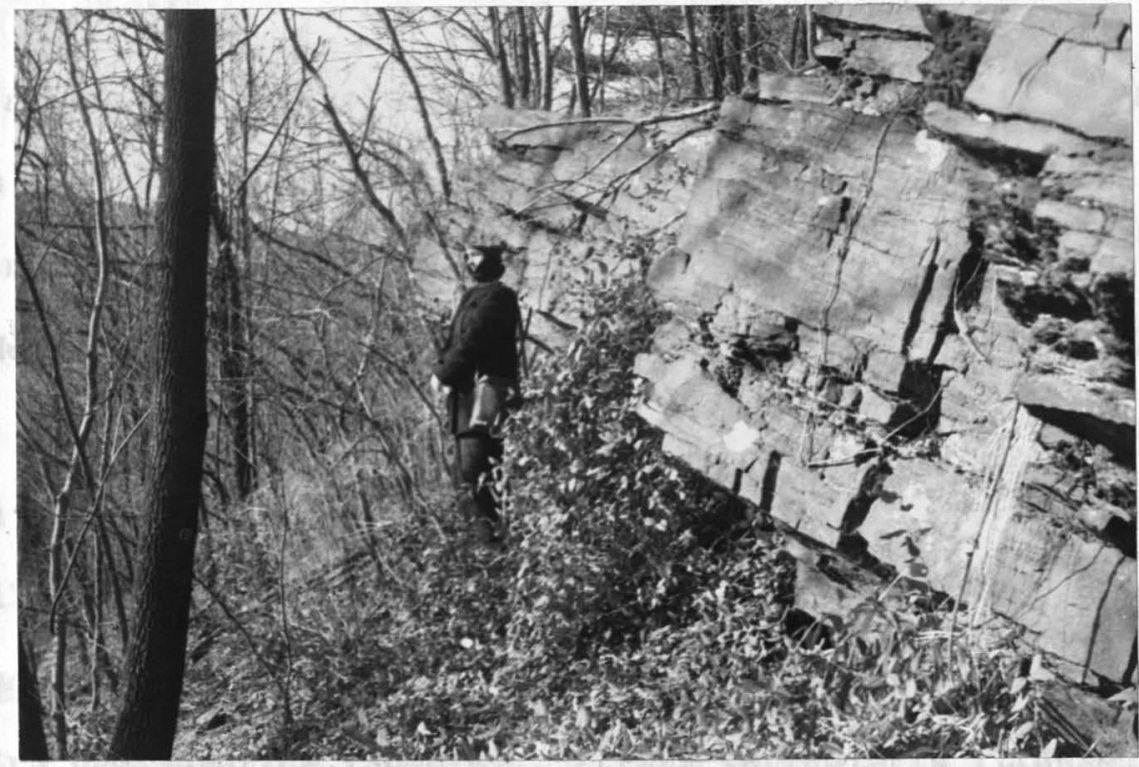

Fig. 6. Ledge of resistant ferruginous Rose Hil1 sandstone in Slaughterback Hi11. Two miles north of Millerstown.

The lower massive bed of ferruginous sandstone crops out along Route 322, just west of the stream flowing from Little Pfoutz Valley into the Juniata two miles northwest of Millerstown. There at road level an outcrop of hard, dense, purple, iron-bearing. quartz sandstones is interbedded with reddish quartz sandstones containing very little iron. The thickness of the iron sandstones ranges from 0.4 to 2.4 feet. One hundred yards east of this outcrop, near the crest of the western extension of slaughterback Hill (see map in appendix), the upper massive iron sandstone forms a ledge dipping $25-35^{\circ} \mathrm{N} 15^{\circ} \mathrm{W}$ on the south flank of the ridge (Figure 6). The crest of this ridge is underlain by the Keefer sandstone. Below the iron sandstone ledge the beds are not exposed but loose float rock consisting of shales, sandstones, and hematite cover the slope.

Near the top of Slaughterback Hill, along the Tuscarora anticline axis, there are a few small exposures of olive-green 
fissile shale and thin argillaceous sandstone. These non-resistant beds have remained so high only because the overlying resistant sandstones protected them from erosion.

Numerous fossils were seen in most outcrops of Rose Hill strata. The beds rich in iron did not contain visible fossils but some showed various sedimentation markings. The following were collected from the Rose Hill formation: Tentaculites minutus Ha11, Mastigobolbina typus $U$ and B, Zygosella postica, Swartz Coelospira hemispherica, (Sowerby), Atrypa reticularis (Linnaeus), and Dalmanella elegantula (Dalman).

\section{KEEFER FORMATION}

The Keefer formation is a very hard, dense, fossiliferous quartz sandstone which is white, buff, or pink in color. In places it is so well cemented with silica it is better described as a subquartzite. The resistant nature of this sandstone has enabled it to form a distinct scalloped ridge along the flanks of Tuscarora Mountain and around S1aughterback Hill. The Keefer sandstone is 40 feet thick in an exposure along Cocolamus Creek two miles south of Wardville. It is exposed on both sides of the river onehalf mile north of Millerstown. Neither of these exposures show more than 12 feet of the Keefer sandstone beds. In both, the Keefer is a medium-grained white fossiliferous sandstone containIng abundant crinoid discs.

In the northwest section of Slaughterback Hill the lower beds of the Keefer sandstone are exposed. At the base a bed of oolitic 
hematite is still exposed from the early excavations made in the search for iron ore. This bed is only a few inches thick and is underlain by other thin but more siliceous iron-rich sandstones. On the south bank of the Juniata along the Pennsy1vania Railroad one mile east of the Thompsontown bridge, the Keefer sandstones are well exposed. There the Keefer sandstones dip $30^{\circ} \mathrm{N}$ and $20^{\circ} \mathrm{W}$ and crop out for about 300 yards along the tracks. The sandstones contain abundant crinoid discs and a few small brachiopods. In the lower beds a zone several inches thick contains angular fragments of oolitic hematite. These fragments are apparently reworked hematite ore beds just below the Keefer and indicate a possible minor unconformity or erosion level.

Due to the distinct topographic expression of the Keefer sandstone it was mapped as a separate formation rather than with the Rose Hill. The Keefer formation interval has been exaggerated in the geologic cross sections included with this report.

The Rochester formation was not recognized in the area but if present would lie above the Keefer sandstone and below the McKenzie limestone and shales. At Lewistown and Mount Union, respectively, 25 and 40 miles west of the Millerstown quadrangle, the Keefer sandstone is overlain by $30-40$ feet of calcareous drab gray fossiliferous shale and occasional thin beds of limestone belonging to the Rochester formation (F. M. Swartz, Pp. 118-119, 1932). John T. Miller reports finding Rochester shales in the Loyville quadrangle which borders the Millerstown quadrangle to the southwest. There the shales are very fossilifexous and 10-15 feet thick (personal communication). The shales are difficult to find in outcrop as they weather rapidly and may be covered with float of the resistant Reefer sandstone. 


\section{MCKRNZIE FORMATION}

The McKenzie formation was named by E. C. V1rich in 1911 for McKenzie Station, Allegany County, Maryland. There the formation is 170 to 300 feet thick and lies between the Bloomsburg red sandstone member of the Wills Creek formation and the underlying Keefer sandstone of the Clinton group (Wilmouth, pp. 1253-1254, 1938). In the Millerstown quadrangle the McKenzie crops out in a belt wrapping around the lower slopes of Tuscarora Mountain and slaughterback Hill. The easily weathered calcareous shales and limestones do not form any natural exposures and only in road cuts could any trace of these beds be found. Partial exposures were seen along Route 322 three miles northwest of Millerstown and in Pfoutz Valley east of Cocolamus Creek. In Little Pfoutz Valley only the top contact with the Bloomsburg red sandstones is exposed. The interval between this contact and the Keefer sandstone forming the north slope of Slaughterback Hill is about 200 feet. The beds dip $30^{\circ}-35^{\circ} \times 15^{\circ} \mathrm{W}$ in both the Bloomsburg and Keefer formations.

The MeKenzie formation is comprised of fossiliferous calcareous shales, argillaceous gray limestones, and thin-bedded blue to black limestones. The upper beds are composed of thin-bedded fossiliferous shales with some calcareous shale interbeds. They are conformably overlain by the Bloomsburg red shales and sandstones.

Calcareous shales and limestones are dominant in the middle and lower beds. Along State Route 322 three miles north of 
Millerstown is an exposure comprised of medium-bedded gray to black fossiliferous limestones interbedded with blue-gray argillaceous limestones and calcareous shales. The black limestone is a coquina of minute ostracods most of which are Eukloedene1la umbilicata, U and B. On long exposure the ostracods weather to a white or very light gray color on the surface.

In Pfoutz Valley just east of Cocolamus Creek about twelve feet of McKenzie olive-gray fissile to platy, fossiliferous shales are exposed along a dirt road. Block-jointed dense crystalline bluish-gray beds of unfossiliferous limestone, three to four inches thick, are interbedded with the shales (Figure 7). Uncinules obsolesens Swartz was the only fossil found identifiable.

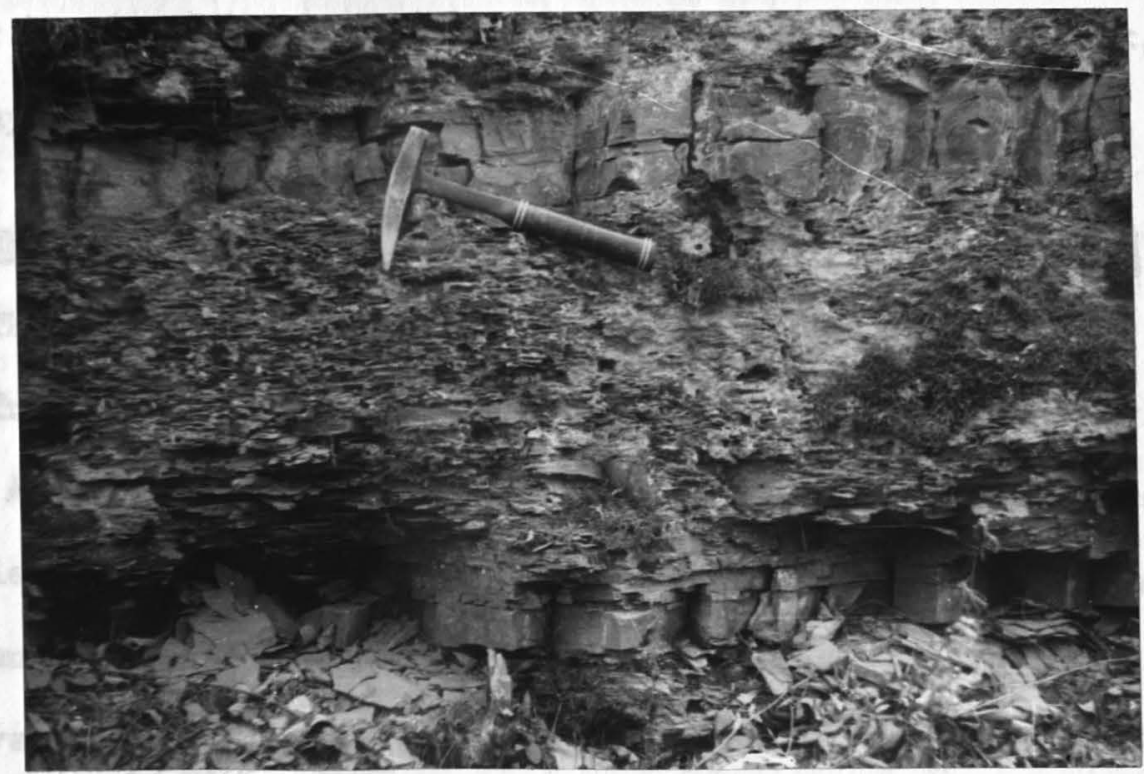

Fig. 7. Fossiliferous McKenzie shales with interbedded limestone. Pfoutz Valley east of Cocolamus Creek. 
Red hackly-weathering shales seventy feet thick occur in an Interval 70 to 140 feet below the Bloomsburg formation at Mount Union, Pennsylvania. There the McKenzie is divided into three units, the lower gray shale and limestone member, the Rabble Run red bed member, and the upper gray shale and limestone member (F. M. Swartz, pp. 121-126, 1934). The Rabble Run red bed member was not seen in the Millerstown area although its presence is indicated by $a$ band of red soll and red shale float within the outcrop area of the yellow weathering McKenzie shales and limestones.

\section{Cayugan Series}

The Cayugan or Upper Silurian series comprises four formaEions with a total thickness of 1780 feet. These formations are, In order of their decreasing ages, the Bloomsburg, Wills Creek, Tonoloway, and Keyser.

\section{BLOOMSBURG FORMATION}

The Bloomsburg red shales were first described by I. C. White (1883) from exposures near Bloomsburg, Columbia County, Pennsy 1vania. At that locality there are 440 feet of dark, deep or du11 red shales and sandy shales. It is a continental facies of the Middle and Upper Silurian limestones and shales. In Eastern Pennsylvania these red beds may occupy the position of the lowex Tonoloway, Wills Creek, Bloomsburg, and upper McKenzie formations. The thickness at Delaware Water Gap, Pennsylvania is about 2000 feet (Swartz and Swartz, pp. 658-661, 1931). The formation thins to the east and is 330 feet at Lewistown, Pennsylvania and only 
locations are respectively 25 and 40 miles west of Millerstown. The Bloomsburg red beds are unfossiliferous and can be correlated only from their stratigraphic position.

The Bloomsburg formation is well exposed in Pfoutz Valley three miles west of Wardville. There the red beds are 700 feet thick and consist of brick red argillaceous to slightly arenaceous shales. The shales weather into irregular hackly and lumpy fragments, and the more arenaceous beds weather to blocky and flaggy fragments. In both the top and lower halves of the formation there are arenaceous zones which approach sandstones in ability to resist weathering and erosion. The topographic expression of the two zones is a pair of parallel, low and smooth ridges. This feature aids in locating and tracing the Bloomsburg formation. The hills are very low in Pfoutz Valley and not easily identified on the topographic map, but they are readily noticed in the field or on the aerial photographs. In Little Pfoutz Valley these hills are distinct and readily apparent even on the topographic map (see geologic map in appendix).

The Bloomsburg formation is along the south slope of Tuscarora Mountain but has no topographic expression and can be traced only from the red color of the soil and loose fragments of the red shale. South of Thompsontown it was seen at only two widely separated exposures as it is covered by thick alluvial deposits. There are numerous exposures in Pfouts Valley where the formation wraps around the Tuscarora anticline axis and crops out over a large area. The most eastern exposures are complicated by subordinate folds of the Tuscarora anticlinorium. The zig-zag pattern of the beds is 
easily followed on aerial photographs due to the more resistant hill-forming sandy zones and the changes in color of the soil.

\section{WIIIS GREEK FORMATION}

The Wills creek formation occupies the interval between the Bloomsburg formation at its base and the overlying Tonoloway formation. This formation in Little Pfoutz Valley is estimated to be 500 feet thick. Much of the section is covered and the dip of the beds changes between exposures, making it difficult to obtain a good measurement.

The lower portion of the formation consists of greenish-gray, thin-bedded shales alternating with equal amounts of red lumpy mudrock. The red beds are interfingering recurrences of the continental deposits which comprise the underlying Bloomsburg formation. Upward these beds are less numerous and are not present in the upper 300 feet of the Wi1ls Creek. The fissile shales weather to a grayish-yellow or light olive gray color on exposure. They contain only scattered ostracod remains. On the infrequently found fresh surface the shales are dark gray or black. The zones of red shale are devoid of fossils and weather to hackly and chippy Eragments (Figure 8).

The upper layers of the Wills Creek become increasingly calcareous and fossiliferous. The olive-gray shales are interbedded with yellowish-gray calcareous shales and argillaceous limestones. A thin bed of gray argillaceous fine-grained sandstone is present in one exposure.

The following fossils were found in the Wills Creek formation of the area studied: Ieperditia alta Conrad, Schuchertella rugosa, 
Swartz, Otenadonta sp.

Valleys commonly develop in outcrop areas of the Wills Creek formation. The soft shales and thin limestones are easily broken down and eroded so that good exposures are difficult to find. The formation crops out in Racoon Valley south of Tuscarora Mountain. There a number of exposures may be seen along the highway near Donnally Mills (Figure 8).

There are scattered exposures in Little Pfoutz Valley from Wardville to Thompsontown and in numerous places along the roads in Pfoutz Valley. A small soil covered area occurs one mile south west of East Salem. Its upper contact was drawn by measuring an interval from the top of the Tonoloway formation.

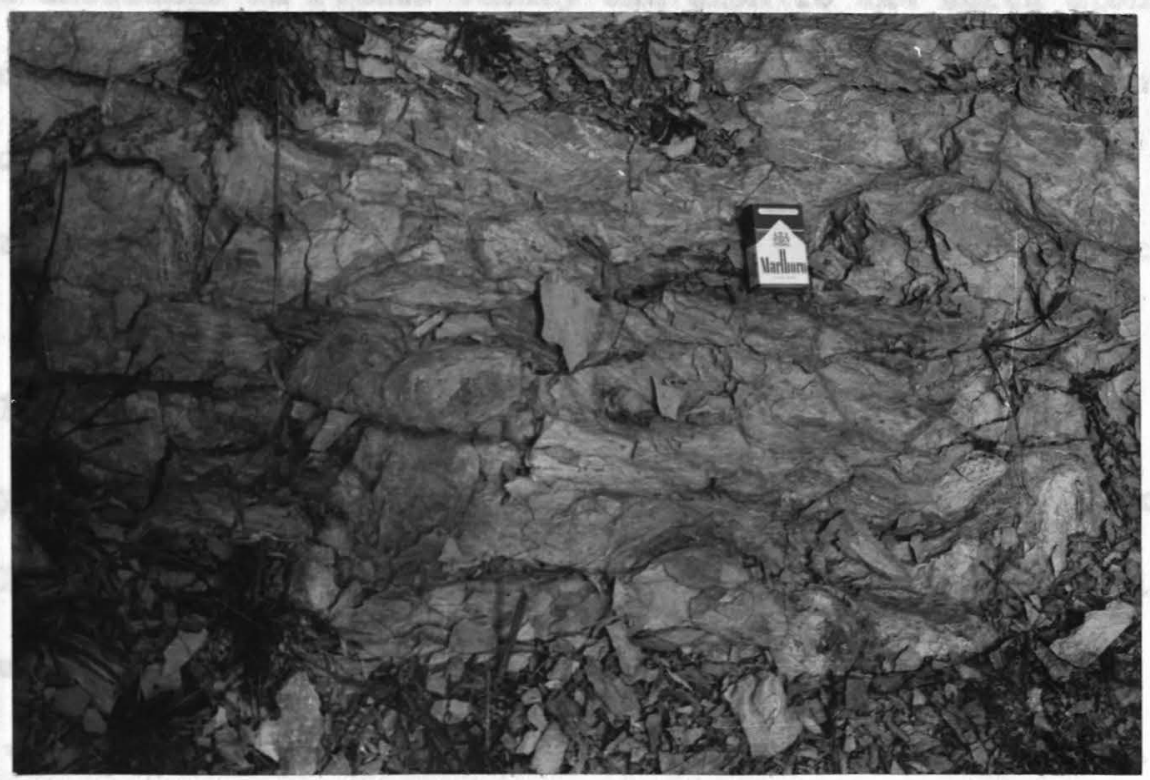

Fig. 8. Bedding plane surface of Wills Greek variegated fissile shales. One mile west of Donnally Mills. 
TONOLOWAY FORMATION

The Tonoloway formation is 350 feet thick where Cocolamus Creek has cut a gap in Turkey Ridge north of Wardville. There the formation consists of thin- to medium-bedded, thin-1aminated, blue-gray Iimestone interbedded with argillaceous limestone and calcareous shales. Ostracods are abundant in zones throughout the formation. On exposure the lamination becomes more distinct due to differential weathering. The shaly layers weather to hackly or fissile buff fragments. The more pure dense platy limestones have a characteristic ring when struck.

The Tonoloway formation crops out just north of Raccoon and Wildcat Ridges with steep dips to the south. This belt crosses the Tuscarora anticline in Pfoutz Valley and dips to the north along the south slope of Turkey Ridge. It forms only low ridges and, other than old abandoned limestone quarries, is seldom exposed. North of Thompsontown the Tonoloway limestones crop out along the flanks of the Academia anticline. The formation there is thick-bedded dense and forms relatively high hills. One mile north of East Salem the Tonoloway formation is well exposed in a large quarry on the axis of an anticline (Figure 10). The Tonoloway strata are nearly horizontal in the quarry. Only a few thin layers of shale are present in the exposure whtch comprises the upper 60-70 feet of the formation. The characteristic thin lamination is well developed throughout most of this exposure. The laminae range in thickness from paper-thin to one-tenth of an inch. One hand specimen from a laminated zone contained a layer of limestone intraformational breceia. In this speci- 
men small thin-1aminated fragments, not oriented parallel to the major laminations, are in a layer three-forths of an inch thick. High angle faults with displacement of only a fraction of an inch have formed minute offsets in the laminae. These features originated before and during compaction and lithification of the sediments. Fossils found in the Tonoloway formation were Schucherte1la rugosa Swartz, Leptaena "rhomboidalis", and Leperditia sp.

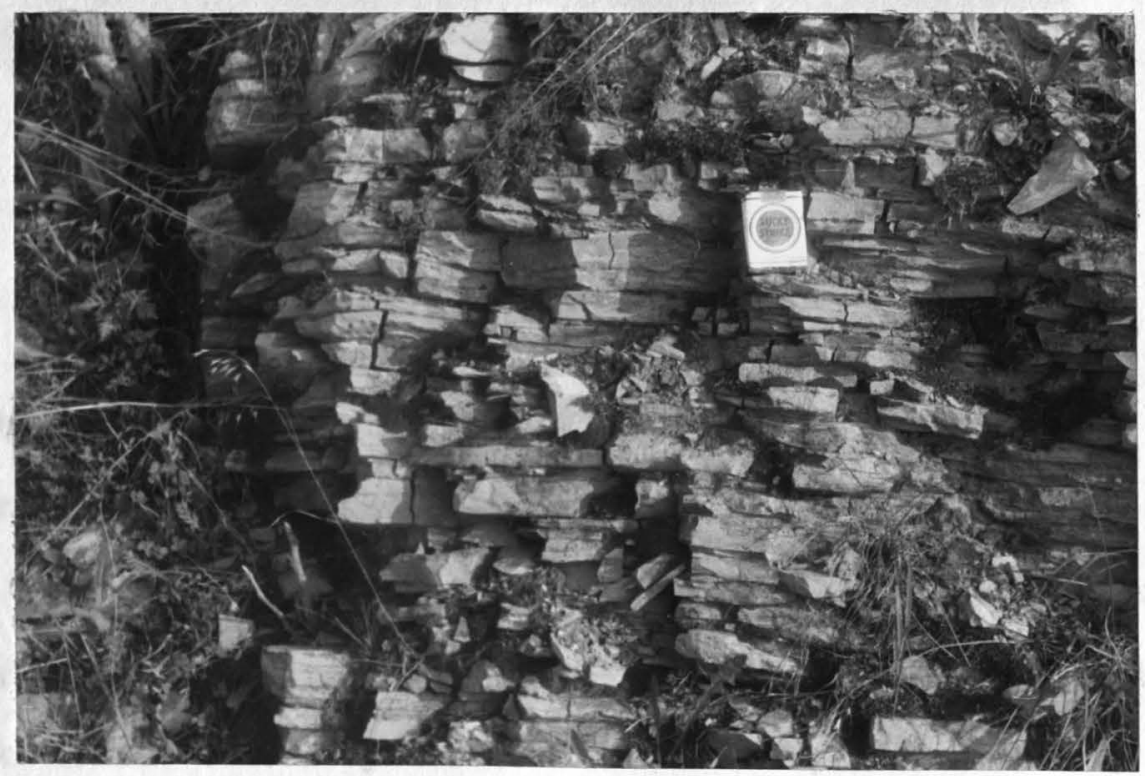

Fig. 9. Thin-bedded and thin-1aminated Tonoloway limestone. One and one-half miles northwest of East Salem.

\section{KEYSER FORMATION}

The Keyser formation is 230 feet thick in the gap north of Wardville. There it is exposed along the east bank of Cocolamus Creek. The lower beds are nodular and lumpy,yellow-weathering thinto medium-bedded fossiliferous blue-black limestone. These are 


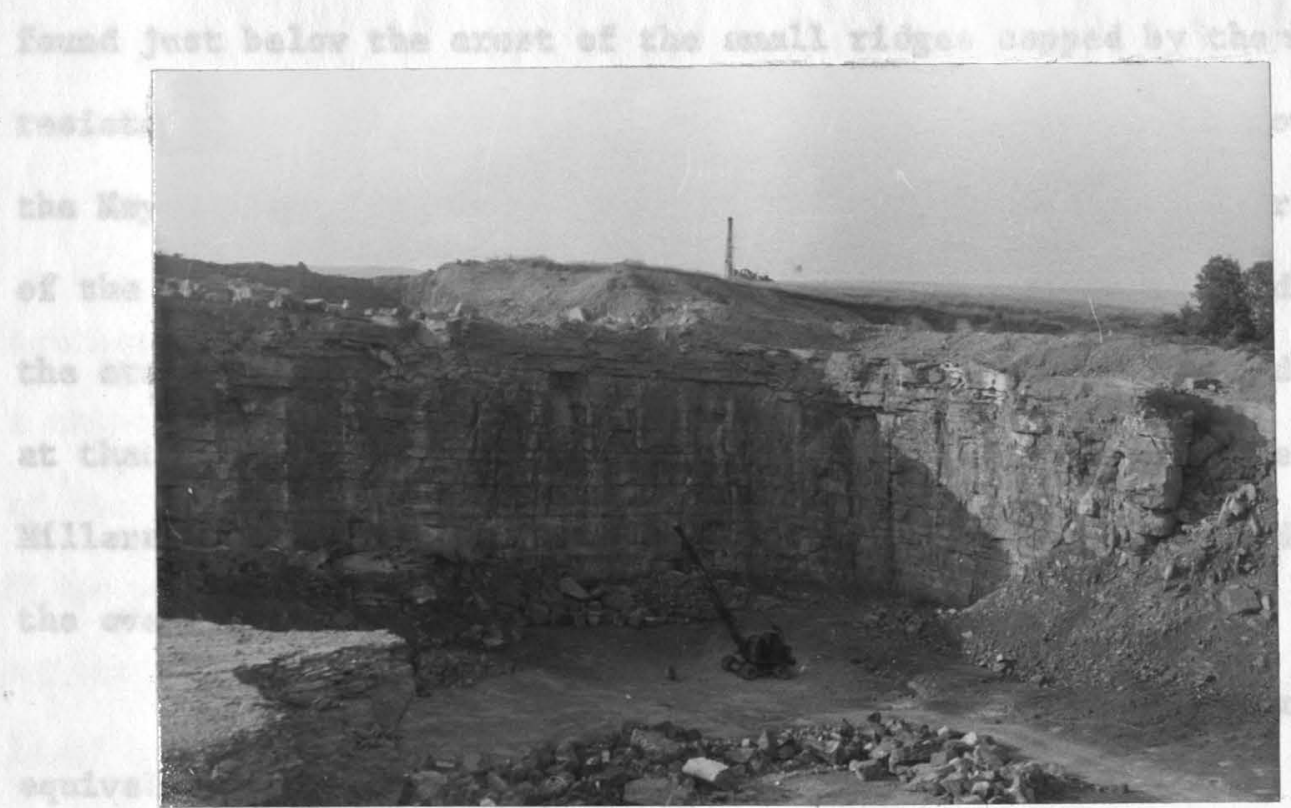

Fig. 10. Quarry in Tonoloway limestone with Keyser limestone at the surface. One mile north of East Salem.

interbedded with layers of greenish-gray weathering fissile or platy calcareous shales. Thin cherty zones appear near the top where the thin-bedded limestone grades into the thick-bedded cherty Helderberg formation. The upper Keyser limestones are thin-bedded and similar to the Tonoloway formation. However, the fossil assemblage of the Keyser is distinctive enough to distinguish the two.

The Keyser limestone crops out along the stream valley north of Raccoon Ridge and along the north flank of Wildcat Ridge. This belt extends nearly the entire width of the area from east to west. The limestone caps the arch of the Tuscarora anticline at its eastern extremity and forms a nearly parallel outcrop along the south flank of Turkey Ridge dipping to the north. The Keyser commonly is 
found just below the crest of the small ridges capped by the more resistant overlying chert. Between East Salem and Thompsontown the Keyser limestone crops out along the flanks of the two branches of the Academia anticline. North of East Salem it is exposed on the crest of the Blacklog Mountain anticline which is coincident at that point with Lost Creek Ridge (Figure 10). East of the Millerstown quadrangle this ridge is monoclinal and is capped by the overlying chert, and the Reyser is on the north slope.

F. M. Swartz (p. 130, 1932) states that the Keyser limestone is equivalent to the Decker, Rondout, and Manlius limestones of New York and New Jersey. These have long been regarded as Silurian in those states, however, the Keyser has generally been included with the Helderberg group of the Devonian in Pennsylvania, Maryland, West Virginia, and Virginia. The true correlation of the Keyser-Helderberg limestones with the Silurian age limestones has been a controversial subject for many years and will continue to be until more research is carried out on the problem. Recent research conducted by the Pennsylvania Geological Survey supports the possibility of the Keyser being the Upper Silurian or of a transitional age. The correlation is as yet inconclusive, and the actual silurian-DevonIan boundary may prove to be in the overlying Helderberg group (Miller, 1957).

As the field work was conducted in Pennsylvania and with the aid of the Pennsylvania Geological Survey, the writer has chosen to place the Keyser in the Silurian system. This choice is not based on any new evidence but only to conform as nearly as possible with the mapping practices of the Pennsylvania Survey. 
DEVONIAN SYSTEM

A complete sequence of Devonian strata crop out within the southern half of the Millerstown quadrangle. These beds attain a thickness of approximately 9400 feet and comprise three-fifths of the surface rocks. The Devonian system within the Valley and Ridge province has numerous subdivisions. Considerable variation exists in the manner in which the system has been subdivided in local areas. The divisions used here have been adapted with slight revisions from a report on the Devonian System of Pennsylvania (Willard, et. al., pp. 17-18, 1939). Figure 11 relates the terms used by the First and Second Geological Surveys of Pennsylwania to the equivalent divisions of the Devonian system chosen for this report. The mapable units were separated on the basis of their lithologies. Some of the distinct lithologic subdivisions were mapped together as a unit due to their thinness in relation to the scale of the base map. Other subdivisions, based largely on paleontologic evidence, were mapped together as one unit for lack of time to make adequate fossil collections necessary to determine the boundaries. The Devonian formations will be considered in the order of their deposition.

\section{Lower Devonian}

The lower Devonian comprises two groups, the Oriskany and the Helderberg. The total thickness of the two groups, in the area mapped, is about 100 feet. On the aerial map and cross sections 


\begin{tabular}{|c|c|c|c|}
\hline $\operatorname{archac} 8 x$ & 1st Survey & 2nd Survey & 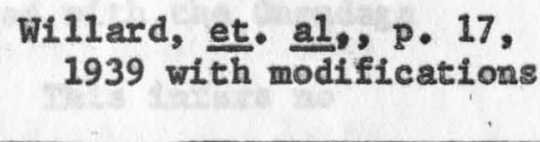 \\
\hline \multirow{2}{*}{$\begin{array}{l}\text { Miss. } \\
\text { System }\end{array}$} & $\begin{array}{c}\text { Umbral } \\
\text { XI }\end{array}$ & $\begin{array}{l}\text { Pocono } \\
\text { sandstone }\end{array}$ & Pocono formation \\
\hline & $\underset{\mathbf{X}}{\text { Vespertine }}$ & $\begin{array}{l}\text { Mauch Chunk } \\
\text { red shale }\end{array}$ & Mauch Chunk fm. \\
\hline \multirow{3}{*}{$\begin{array}{l}\text { Upper } \\
\text { Devonian }\end{array}$} & Ponent IX & $\begin{array}{l}\text { Catskill } \\
\text { red ss \& sh }\end{array}$ & Catskill fm. \\
\hline & \multirow{3}{*}{ Cadent } & $\begin{array}{c}\text { Chemung } \\
\text { sandstone } \\
\end{array}$ & Chemung fm. \\
\hline & & $\begin{array}{c}\text { Portage } \\
\text { shale }\end{array}$ & $\begin{array}{l}\text { Portage gr. } \\
\text { Trimmers Rock ss. } \\
\text { Brallier sh. } \\
\text { Harrell sh. } \\
\text { Burkett sh. } \\
\text { Tully } 1 \mathrm{~s} . \\
\end{array}$ \\
\hline \multirow{2}{*}{$\begin{array}{c}\text { Middle } \\
\text { Devonian }\end{array}$} & & $\begin{array}{l}\text { Hamilton } \\
\text { sandstone }\end{array}$ & $\begin{array}{l}\text { Hamilton fm. } \\
\text { Mahantango sh. } \\
\text { Montebello ss. }\end{array}$ \\
\hline & \multirow{2}{*}{ betax } & $\begin{array}{c}\text { Marcellus } \\
\text { shale } \\
\end{array}$ & $\begin{array}{l}\text { Marcellus formation } \\
\text { Mahanoy sh. } \\
\text { Mexico ss. } \\
\text { Turkey Ridge ss. } \\
\text { Shamokin sh. }\end{array}$ \\
\hline base of & & $\begin{array}{l}\text { Corniferous } \\
\text { 1s and sh }\end{array}$ & $\begin{array}{l}\text { Onandaga fm. } \\
\text { Selinsgrove 1s. } \\
\text { Needmore sh. }\end{array}$ \\
\hline \multirow{2}{*}{$\begin{array}{l}\text { Lower } \\
\text { Devonian }\end{array}$} & $\begin{array}{l}\text { Meridian } \\
\text { VII }\end{array}$ & $\begin{array}{l}\text { Oriskany } \\
\text { sandstone }\end{array}$ & $\begin{array}{l}\text { Oriskany group } \\
\text { Ridgeley s8. } \\
\text { Shriver chert }\end{array}$ \\
\hline & $\begin{array}{l}\text { Pre-meridian } \\
\text { VI }\end{array}$ & $\begin{array}{l}\text { Lower Helderberg } \\
\text { limestone }\end{array}$ & $\begin{array}{l}\text { Helderberg group } \\
\text { Mandata sh. } \\
\text { New Scotland 1s. } \\
\text { Coeymans is. }\end{array}$ \\
\hline
\end{tabular}


(Appendix) the Lower Devonian has been combined with the Onondaga group of middle Devonian age as one map unit. This infers no anomalous relationship, either lithologic or paleontologic, among the three groups.

HETDERBBRG GROUP

This group is made up of three members, the Mandata shale, New Scotland Iimestone, and Coeymans 1imestone. The group attains a thickness of about 60 feet in the area.

Coeymans 1imestone

The Coeymans limestone has been considered the basal member of the Devonian system in New York since 1899. J. B. Reeside placed the Coeymans at the base of the Devonian in central Pennsylvania in 1918. F. M. Swartz later agreed with Reeside in a study of the Helderberg group of Pennsylvania (Willard, et. al., pp. 47-50, 1939). Geologists of Maryland, Virginia, and West Virginia have not accepted this division and place the Devonian-Silurian boundary at the base of the Keyser limestone.

The thickness is about 50 feet at the type locality near Coeymans, New York, where it is described as consisting of hard massive bluish-gray limestone. At Clarks Mill near New Bloomfield, five miles south of the Millerstown quadrangle, the Coeymans is reported to be 7 feet thick (W11lard, et. al., P. 83, 1939). Its presence is also reported from the Loysville quadrangle bordering the southwest corner of the area discussed in this report (Miller, 1957). 
The only known exposure in the Millerstown area is in the gap through Turkey Ridge a half mile north of Wardville. There about 4 feet of bluish-gray, thick-bedded, very crystalline limestone is exposed along the east bank of Cocolamus Creek. The Iimestone is fossiliferous containing crinoid stem fragments and brachiopods. It overlies the thin-bedded upper Keyser limestone, although the actual contact is covered. The lithologic character and stratigraphic position of the beds exposed leave little doubt of its Identification as the Coeymans 1imestone. The total thickness is probably not much more than that exposed.

\section{New Scotland limestone}

The New Scotland consists of impure cherty limestone and calcareous shale at the type locality in eastern New York. In an exposure near Mandata, Northumberland County, ten miles east of the Millerstown quadrangle, the New Scotland is a thick-bedded crystalline blue-gray fossiliferous limestone only 9 feet thick. At Glarks Mill five miles south of the quadrangle, the New Scotland interval Is represented by a medium-bedded calcareous sandstone 20 feet thick. It has been named the Falling Spring sandstone from an exposure a few miles south of New Bloomfield (Willard, et. al., p. 57, 1939). This sandstone may be continuous with or equivalent to the Healing Springs sandstone member of the New Scotland formation in Virginia and West Virginia.

In the gap north of Wardville, a zone of cherty and shaly limestone float overlying the Coeymans limestone probably represents the New Scotland interval. However, the characteristic inder 
fossil Eospirifer macropleurus was not recognized in the float rock.

Mandata shale

The Mandata shale and chert beds were named by F. M. Swartz For an exposure near Mandata, Northumberland County, ten miles east of the Millerstown quadrangle. This member correlates with the Licking Creek limestone of Maryland, Virginia, and West Virginia. It also occupies the same stratigraphic position as the Beecraft and Port Ewen shales in northeastern Pennsylvania, northern New Jersey, and southeastern New York. The Mandata is recognized in south-central Pennsylvania as the uppermost member of the Helderberg group. It underlies the Oriskany chert and overlies the New Scotland limestone. The Mandata shale is about 90 feet thick at its type locality (willard, et. aㅡ., PP. 62-91, 1939).

Good exposures of the shales are difficult to find as they weather rapidly and soon become covered with debris. No exposures of the Mandata were seen in the mapped area although loose fragments of soft yellowish-weathering shale and black chert indicate its presence below the massive beds of white Oriskany chert. A fair exposure was seen along Pennsylvania Route 104 five miles north of Liverpool and two miles east of the Millerstown quadrangle (Fig. 1). There the Oriskany chert beds are underlain by yellowish-orange weathering, thin-bedded, non-calcareous, shales containing a few interbedded dark cherty layers. 
ORISTANY GROUP

The Oriskany group comprises the Ridgeley sandstone, where present, and the Shriver chert. The combined thickness of the two members probably nowhere exceeds 40 feet in the area studied.

\section{Shriver chert}

The Shriver chert of the Oriskany group overlies the Mandata shales and underlies the Ridgeley sandstone. In the absence of the sandstone the chert is in direct contact with the Onondaga of middle Devonian age. It has been suggested by A. B. Cleaves (Willard, et. al., p. 97, 1939) that the chert may be younger than the type Shriver of Maryland and possibly a local facies of the Ridgeley sandstone. This possibility could be determined only by Intensive paleontologic research. It is here considered Shriver chert in light of more recent work by H. P. Woodward (1957) in which the lack of Oriskany sandstone deposition is attributed to a structural feature (see section on Structural Geology).

In the gap through Turkey Ridge, one-half mile north of Wardville, 40 feet of white and gray, medium-bedded, block-jointed, fossiliferous chert is exposed. The chert is overlain by black calcareous Onondaga shales. Although no sandstone is present the uppermost chert beds are slightly arenaceous. The Shriver is persistent throughout the area and can be readily traced by the distinctive ridge capped by the hard chert. Even where the ridge is not well developed the approximate position of the outcrop can be determined by abundant angular white chert fragments which cover the surface for some distance down slope from the source beds. 
Ridgeley sandstone

The Ridgeley sandstone is not well developed and in much of the area it is entirely absent. One mile southwest of East Salem an exposure shows 6 feet of buff-yellow weathering, very porous, quartz sandstone which is thick-bedded and fossiliferous. The quartz is medium sand size, sub-rounded to rounded, and loosely

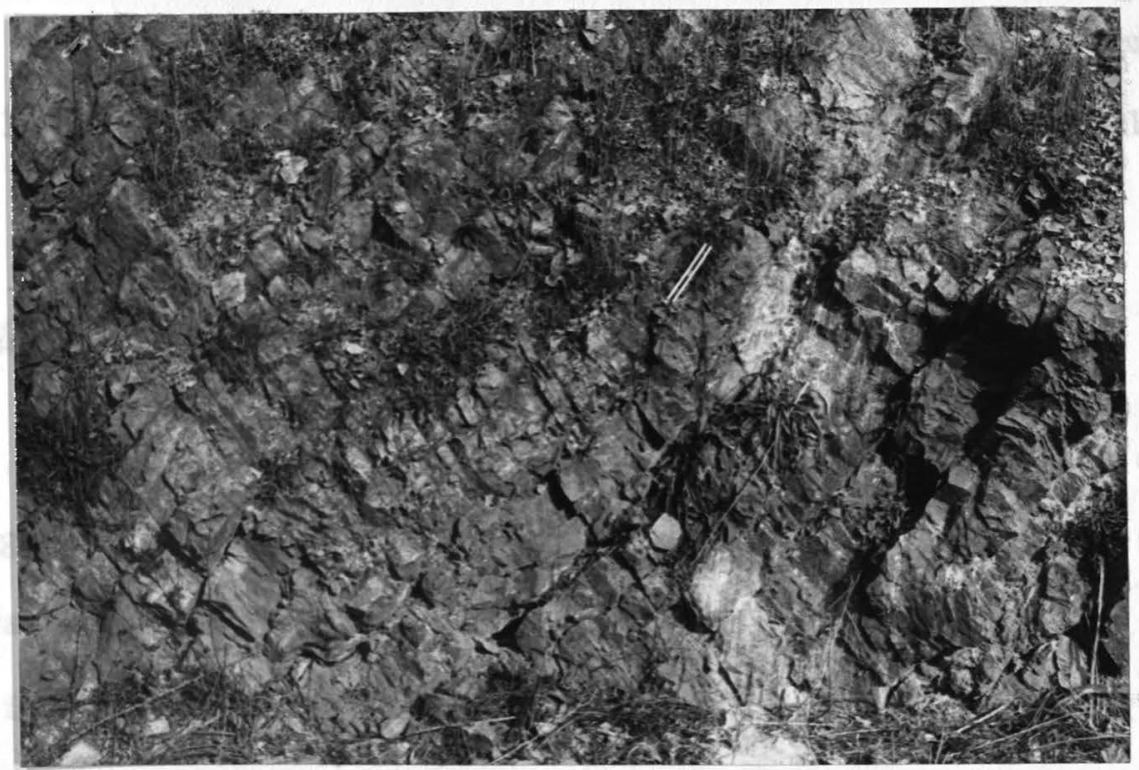

Fig. 12. Well exposed Shriver chert along Pennsylvania Route 104 five miles north of Liverpool. Six inch ruler lies approximately parallel to the bedding.

cemented. A few grains have developed crystal faces by secondary growth of silica on the detrital quartz. The characteristic Costispirifer arenosus Conrad is very abundant throughout the sandstone. The Ridgeley was not seen east of Delaware Creek. Westward the sandstone becomes thicker and is 190 feet thick at Mapleton, approximately thirty-five miles from the Millerstown quadrangle 
(willard, et. al., p. 123, 1939).

Absence of the Ridgeley sandstones, in the outcrop belt of Oriskany strata extending through Pfoutz Valley to the eastern border of the quadrangle, may be explained by the presence of a buried arch of early Paleozoic age (Woodward, 1957). This phenomenon is discussed in the section on geologic structure.

\section{Middle Devonian}

The Middle Devonian series is subdivided into the Onondaga, Marcellus and Hamilton formations. The total thickness of these in the area studied is about 1700 feet.

\section{ONONDAGA FORMATION}

The Onondaga is composed of the Needmore shale below and the Selinsgrove limestone above. The combined thickness of the two members is about 55 feet. The Onondaga formation in central Pennsylvania is defined to include all strata between the overlying Marcellus and the underlying Oriskany formations. On the geologic map and cross sections the Onondaga has been grouped with the Oriskany and the Helderberg formations.

Needmore shale

The Needmore shale is not well exposed in the area but its presence is indicated by shaly debris overlying the oriskany formation. These olive-drab weathering black shales were seen in the section one-half mile north of Wardville and overlying the Ridgeley sandstone in the exposure one mile southwest of East Salem. The 
thickness is probably not more than 10 feet at either exposure.

The Neednore is equivalent to the Esopus shale of eastern Pennsylvania and possibly in part to the liuntersville chert of West Virginia and Virginia. In much of West Virginia, Virginia and Maryland the Onondaga is composed of only the Needmore shale and the upper limestone beds are absent.

\section{Selinsgrove 1imestone}

The Selinsgrove lower limestone and Selinsgrove lower shale were described by I. C. White (pp. 79-81, 1883) from an exposure twelve miles northeast of the area discussed in this report. The Selinsgrove lower shale is now known as the Needmore shale and the Selinsgrove lower limestone has been retained after dropping a portion of the original term. At the type locality the Selinsgrove is 65 feet thick and described as a dark-gray to black nomcherty limestone. The Selinsgrove limestone is equivalent to the Buttermilk Falls cherty limestone of eastern Pennsylvania. Along Cocolamus Creek a half mile north of Wardville the Selinsgrove limestone is well exposed. There is about 50 feet of black cryptocrystalline medium-bedded limestone exposed in the east bank and in a private road parallel to the creek. The contact with the Marcel lus is conformable but the break is sharp. Another good exposure is along Delaware Creek two miles north of Thompsontown. There the black thick-bedded limestones, containing a few thin shaly beds are exposed in a road cut. The contact with the overlying Marcellus black shale is now covered but it is reported 
to contain a thin sandstone bed which suggests an unconformity (willard, et. al., p. 148, 1939). In Perry County, south of the Millerstown quadrangle, a friable brown ferruginous sandstone separates the Marcellus shale and Selinsgrove limestone. This bed was once mined as an iron ore near New Bloomfield and Newport (Claypole, pp. 96-99, 1885).

The upper contact is exposed in Turkey Ridge one mile northeast of Thompsontown. There the Marcellus black shales overlie a very dense black cryptocrystalline limestone which breaks with a conehoidal fracture.

\title{
MARGELLUS FORMATION
}

Locally the Marcellus formation comprises the following four members :

\author{
Mahanoy black shale \\ Mexico sandstone \\ Turkey Ridge sandstone \\ Shamokin shale
}

The, sandstone members are present in Perry, Juniata, Dauphin, Northumberland, and Snyder Counties. In general the sandstone section is thicker at its southern margin and thins out to the north and northwest. The Mexico sandstone takes its name from a small village six miles east of Thompsontown. It is described as a fine grained, light gray to whitish platy sandstone which weathers brown. The lower Turkey Ridge sandstone takes its name from the ridge just north of Thompsontown. This sandstone is flaggy to massive, comparatively coarse, hard, and olive gray in color. Neither of the sandstones contain fossils (Willard, et. al., p. 174, 1939). 
The writer found the two units to be indistinguishable in the field as they weather to the same color and show little if any difference in grain size. A specimen from the sandstone at: Donnally Mills gap contains angular medium sand size detrital quartz which is well cemented with ferruginous and argillaceous material.

Although the sandstone members are much harder than the surrounding shales they break down readily and seldom form more than a slight bench on the slopes below the ridge-forming Montebello sandstone. The combined thickness of the Mexico and Turkey Ridge

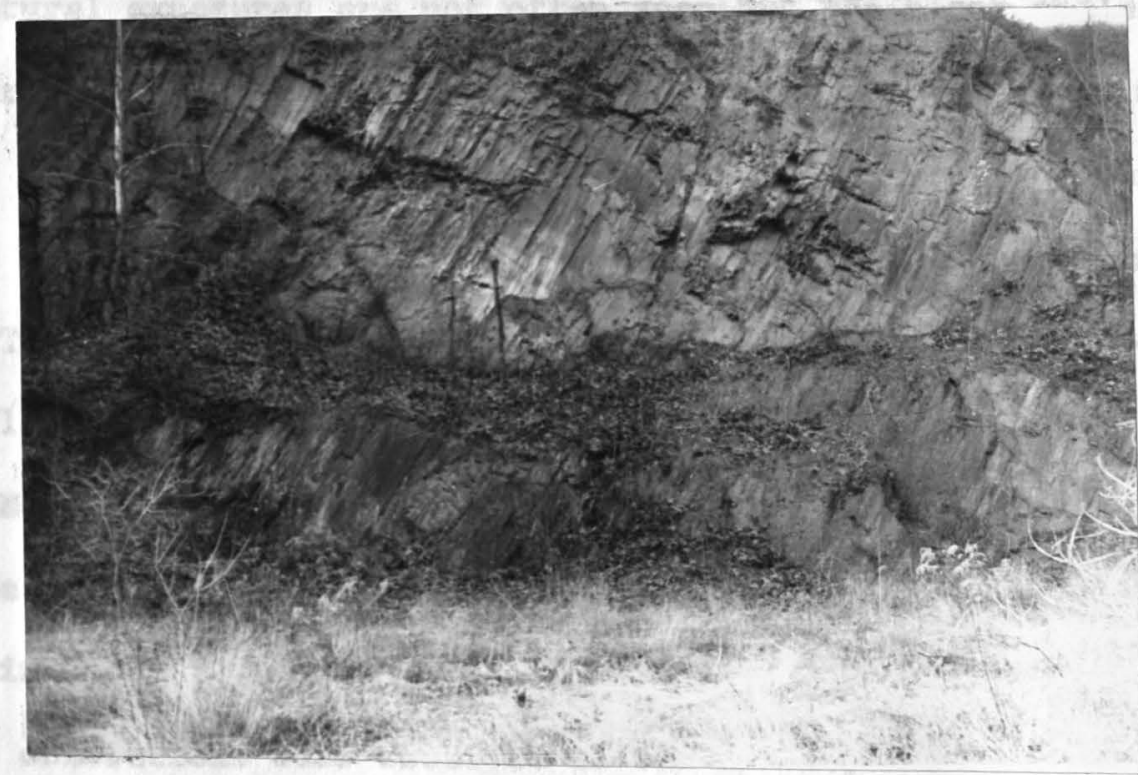

Fig. 13. Mahanoy upper black shale member of the Marcellus formation exposed in gap south of Donnally Mills.

sandstone members is about 200 feet in exposures near Thompsontown and Donnally Mills. These members were not seen in the vicinity of East Salem. This is probably due to thinning or lack of deposition. 
The Mahanoy upper black shale and the Shamokin lower black shale are indistinguishable unless both are exposed. The names are derived from Mahanoy Township and Shamokin Creek in western Northumberland County. These members are composed of massive-bedded black shales which weather to fissile or splintety fragments (Figure 13). They contain a few scattered fossils all of which are characteristically small. Paracyclas lirata (Conrad) and Styliolina fissurella (Hall) ... were identified from the lower member. In the exposure near Donnally Mills the Mahanoy and the Shamokin members are respectively 105 and 95 feet thick.

Natural exposures are not often seen but the black shales were once quarried for use in road building and the openings afford many excellent exposures. The Marcellus sandstone and shale crop out along the north slope of Raccoon and Wildcat Ridges and the south slope of Turkey Ridge. North of Thompsontown the Marcellus crops out on both flanks of the Academia anticline and on the south flank of the Blacklog Mountain anticline.

The characteristic calcareous concretions which are usually abundant in the Marcellus black shales are noticeably absent in this area. No concretions were observed in the Mahanoy shale member and only a few slightly calcareous zones were seen at the base of the Shamokin member. It seems significant that the concretions are absent in the area containing the Mexico and Turkey Ridge sandstone members. Concretions have been reported in the Marcellus formation in all directions surrounding the area in which sandstones were deposited. 
A possible origin of the Marcellus sandstone members is discussed by Bradford Willard (pp. 215-221, 1935). Willard proposes that elevation of the sediments south of the Mexico-Turkey Ridge sandstone region caused erosion of the Oriskany sandstone deposits. The Onondaga and Helderberg formations being largely calcareous left no reworked residue. The Turkey Ridge member is said to be merely reworked Oriskany sandstone although it is finer textured, angular, and barren of fossils. Further evidence is the absence of the Oriskany sandstone in the region south of the Marcellus sandstone deposition. This theory is not in accord with that expressed by H. P. Woodward (1957). Woodward states that the Oriskany was probably never deposited in southern Perry and Dauphin Counties. The latter possibility is discussed further in the section on geologic structure.

\section{HAMTLTON FORMATION}

The Hamilton formation as here used comprises the Tully limestone, Mahantango sandstone and shale, and the Montebello sandstone. The total thickness in the Millerstown quadrangle is about 1250 feet.

\section{Montebe110 sandstone}

The Montebello sandstone was named for an exposure along Little Juniata Creek five miles south of the Millerstown quadrangle (Claypole, pp. 67-68, 1885). The areal distribution of the Montebello is approximately the same as that of the Mexico and Tuxkey Ridge sandstone members of the Marcellus formation. The origin of 
the Montebello sandstone is probably due to a reccurrence of the conditions existing during deposition of the Marcellus sandstone members. Between the two periods, in which sandstone was deposited locally, normal deposition of black shale took place. The Shamokin upper black shale member of the Marcellus was deposited during this interval. The Montebello sandstone is very similar to the Mexico and Turkey Ridge sandstones, although it is fossiliferous and generally coarser in texture. The Montebello is a prominent ridge former. Raccoon, Wildcat, and Turkey Ridges are capped by this resistant sandstone (Willard, et. al., pp. 195-200, 1939). In a nearly complete exposure at the east end of Raccoon Ridge, the Montebello sandstone member is about 950 feet thick. This member consists largely of medium-bedded gray sandstone which weathers to a brown color. On long exposure the sandstone breaks into angular blocks which become bleached white on the surface. The sandstone is interbedded with occasional gray shale zones which weather with a yellowish brown stain. The shale beds become more abundant in the lower portions of the Montebello. Conglomeritic zones, with angular detrital quartz from one- to two-tenths of an inch in diameter, are exposed at numerous intervals. A few quartzpebble conglomerates contain rounded pebbles up to one-half an inch in diameter. Fossils were observed in the upper sandstone and shale beds. Orthonata undulata Conrad and Spirifer audaculus (Conrad) were the only fossils identified from the Montebello. 


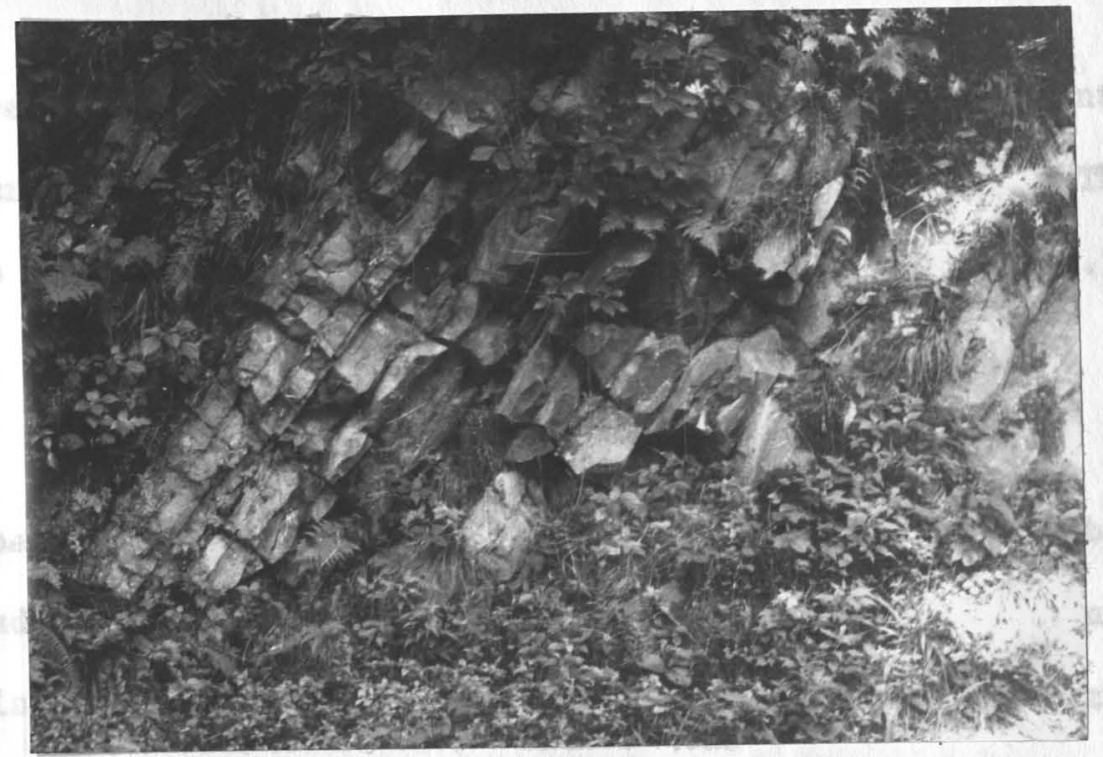

Fig. 14. Montebello sandstone exposed in gap south of Donnally Mills.

Mahantango shale.

The name Mahantango was introduced by Bradford Willard (p. 202, 1935) to include all beds between the Marcellus and Portage formations. This interval was ranked as a formation within the Hamilton group which also included the Marcellus and Onondaga formations. The Montebello sand stone was made a member of the Mahantango formation. In this report they are given equal rank as members of the Hamilton formation. The type locality is along the north branch of Mahantango Creek in Snyder and Juniata Counties. This is north of the area in which the Montebello sandstone was deposited.

The Mahantango consists of dark gray finely axenaceous shale and fine-grained dark-gray argillaceous sandstone. The sandstone 
is thin-bedded and weathers to yellowish brown flaggy fragments. Fossils are abundant in both the shale and sandstone beds. The thickness is about 300 feet at the east end of Raccoon Ridge.

\title{
Upper Devonian
}

The Upper Devonian includes all strata between the Mahantango shales and the basal Mississippian sandstones. In central Pennsy1vania this comprises the Portage, Chemung and Catskil1 formations or groups. In the Millerstown quadrangle these three units have a total thickness of about 7600 feet.

\section{PORTAGE FORMATION}

The Portage formation has many local subdivisions. The following members have been recognized as persistent throughout south-central Pennsylvania (Willard, et. al., Figure 93, 1939):

$$
\begin{aligned}
& \text { Portage formation } \\
& \text { Trimmers Rock sandstone } \\
& \text { Brallier shale } \\
& \text { Harrell shale } \\
& \text { Burket shale } \\
& \text { Tully limestone }
\end{aligned}
$$

On a lithologic basis only the break between the Brallier and Harrell members could be distinguished. The thickness of this formation, including the Chemung if present, is about 3150 feet. Many zones in the Portage formation are profusely fossiliferous. The following fossils were identified from the Portage formation:

\author{
Atrypa reticularis (Linnaeus) \\ Atrypa spinosa Hal1 \\ Gypricardella marylandica C \& S \\ Grpricardinia elegans Hal1 \\ Douvillina cayuta var. graciliora C \& S \\ Osthoceras sp.
}


Paracyclas elliptica Hall

Spirifer (Delthyris) mesacostalis Hall

Spirifer mucronatus var. posterus Hall and Clark.

\section{Tul1y limestone}

The Tully limestone is here considered the basal member of the Portage graup in central Pennsylvania. Its actual position is not clear and it is sometimes interpreted as the uppermost member of the Middle Devonian (Cleaves and Stephenson, Plate 1, 1949). At Half Falls Mountain, two miles south of the Millerstown quadrangle, the Tully is 10 feet thick and consists of gray fissile shale and thin limestones. An exposure of limestone, just north of the junction of Sugar Run with the Juniata, is believed to be the Tully. There an exposure shows 4 feet of very shaly, fossiliferous limestone. This is the approximate horizon occupied by the Tully although it may be only a calcareous bed within the Hamilton formation.

\section{Burket and Harrell shales}

The Burket and Harrell fossiliferous shales are best exposed near the mouth of Sugar Run, one mile south of Millerstown. They are not completely exposed but occupy an interval of about 200 feet. The shales are dark gray to black when fresh and weather into limonite-stained fissile and platy fragments (Figure 15). Although the two members may be separated by their faunal assemblages they are very similar lithologically and could not be easily separated on this basis. The lower black shale beds are equivalent to the 
Genessee shale member of the Jennings formation in Maryland (Willard, et. al., p. 238, 1939).

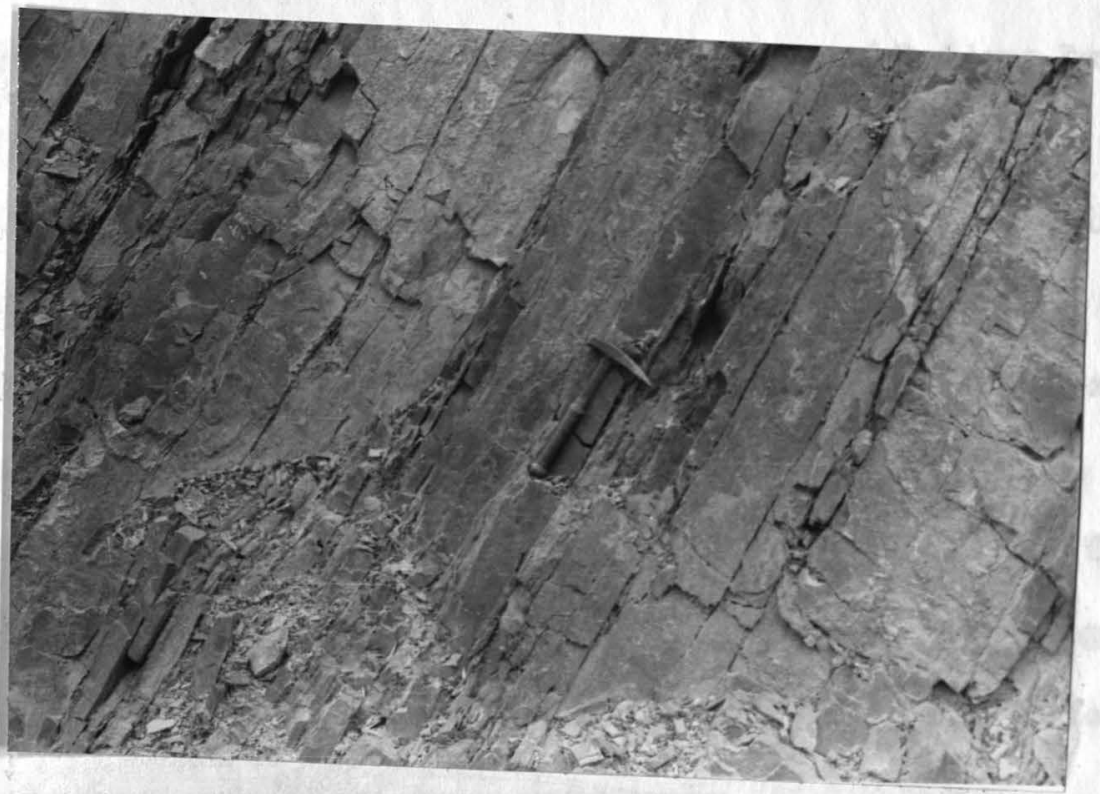

Fig. 15. Burket-Harrel1 dark-gray fossiliferous shales. Freshly exposed road cut one mile south of the Millerstown bridge on west side of river.

Brallier shale and Trimmers Rock sandstone

The dark Burket-Harrell shales grade upward with no distinct boundary into greenish-gray and gray, fine-grained sandstone and arenaceous shale (Figure 16). These are the Brallier and Trimmers Rock members of the Portage group. The sandstones become more dominant upward but there is no break between a shale unit and a sandstone unit. Possibly the largest portion of the interval should be included in the Trimmers Rock member. Near the top of the Trimmers Rock member is a zone of thick-bedded sandstone. This may represent 
the Parkhead sandstone of northeastern West Virginia and western Maryland.

The Brallier-Trimmers Rock interval is well exposed along the west bank of the Juniata, between the junctions of Reiders Run and Sugar Run. These members are also partly exposed on the opposite side of the river. An excellent exposure of the Brallier-Trimmers Rock strata was observed along U. S. Route 22 and 322 across the river from Newport. This is two miles south of the Millerstown quadrangle. In this section the interval between the darker lower Portage shales and the Catskill type red beds is about 2950 feet. The entire Upper Devonian is exposed in this section starting a half mile south of the Newport bridge and continuing north for two miles ending in the Millerstown quadrangle.

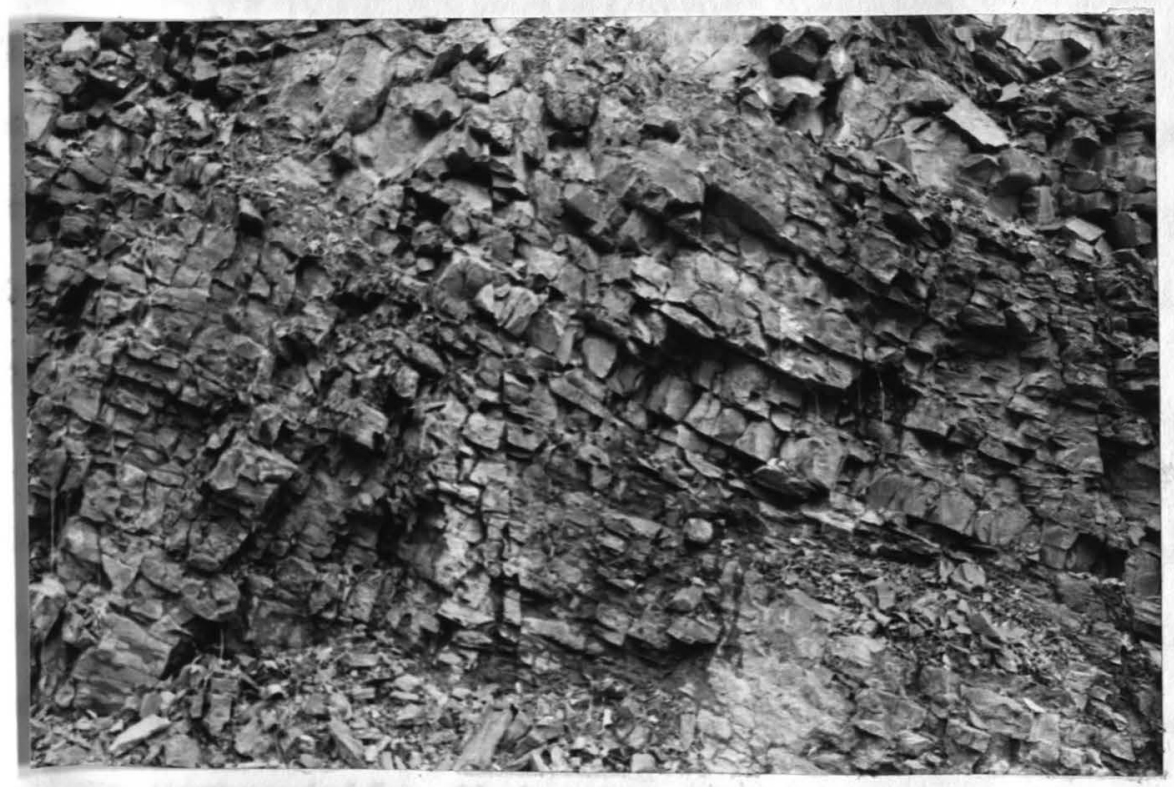

Fig. 16. Trimmers Rock sandstone exposed two miles north of Seven Stars. Note the vertical fault just left of center. 
The Trimmers Rock sandstone is responsible for a number of low rounded ridges in the area. The highest and most notable is Hominy Ridge parallel to and south of Raccoon Ridge.

\section{CHEMMNG EORMATION}

In the Perry County report (Claypole, pp. 36, 1885) 3000 feet of sandstone and shale below the Catskill formation were assigned to the Chemung formation. Only 500 feet of Portage and Genessee shales occupied the interval above the Hamilton and below the Chemarng formations. In the more recent Devonian report (Willard, et. al., pp. 353-357, 1939) only a few feet are assigned to the Chemung formation in Perry County. In the report Willard points out that the base of the Chemung can not be established on a lithologic basis, but can only be drawn at the base of the characteristic Gyrtospirifer disjunctus faunizone.. Willard states that the discrepancy in determining the thickness of the Chemung resulted from failure to distinguish Gyrtospirifer disjunctus from other similar species. It is clear that Claypole's Chemung is largely equivalent to the Trimmers Rock sandstone described by Willard.

No Cyrtospirifer disjunctus were found during this investigation in the well exposed transitional beds between the Trimmers Rock sandstone and the Catskill continental beds. Therefore it is the opinion of the writer that the Catskill transgression reached this area before Cyrtospirifier disjunctus time, and no true Chemung marine beds exist. 
CATSKTII FORMATTON

Overlying the fossiliferous marine deposits are a monotonous succession of red sandstones and shales with an occasional olivebrown or olive-gray sandstone lens. This is the Catskill continental facies which has a thickness of 4500 feet in the Millerstown ares. This thickness was obtained in a sectinn opposite Newport, largely in the New Bloomfleld quadrangle. The base of the formation is exposed along U. S. Route 22 and 322 near a small stream three-fourths of a wile north of the Newport bridge. The upper contact with the Pocono sandstone is on the nose of Buffalo Mountain just within the Millerstown quadrangle. The transitional beds at the base of the Catskill formation occupy a large interval and contain no known reliable marker for separating the maxine and non-marine formations. The boundary is here defined as the point at which the red beds become dominant over the non-red beds. Even this boundary is not precise but serves to separate the two 1ithologies. Medium- to thick-bedded unfossiliferous sandstone lenses are present throughout the Catskill formation. These are typical roll-bottom, channelfill type deposits and often show well developed cross-bedding (Figure 17). A few thin zones of greenish-yellow shales are also found interbedded with the red sandstones and shales.

The fine-grained red sandstones often show faint cross-bedding and are somewhat lenticular, but less so than the non-red sandstones. Ripple-marks are found on the bedding surfaces at many horizons throughout the formation. The red shales weather into hackly or chippy fragments while the sandstones become platy upon weathering. 


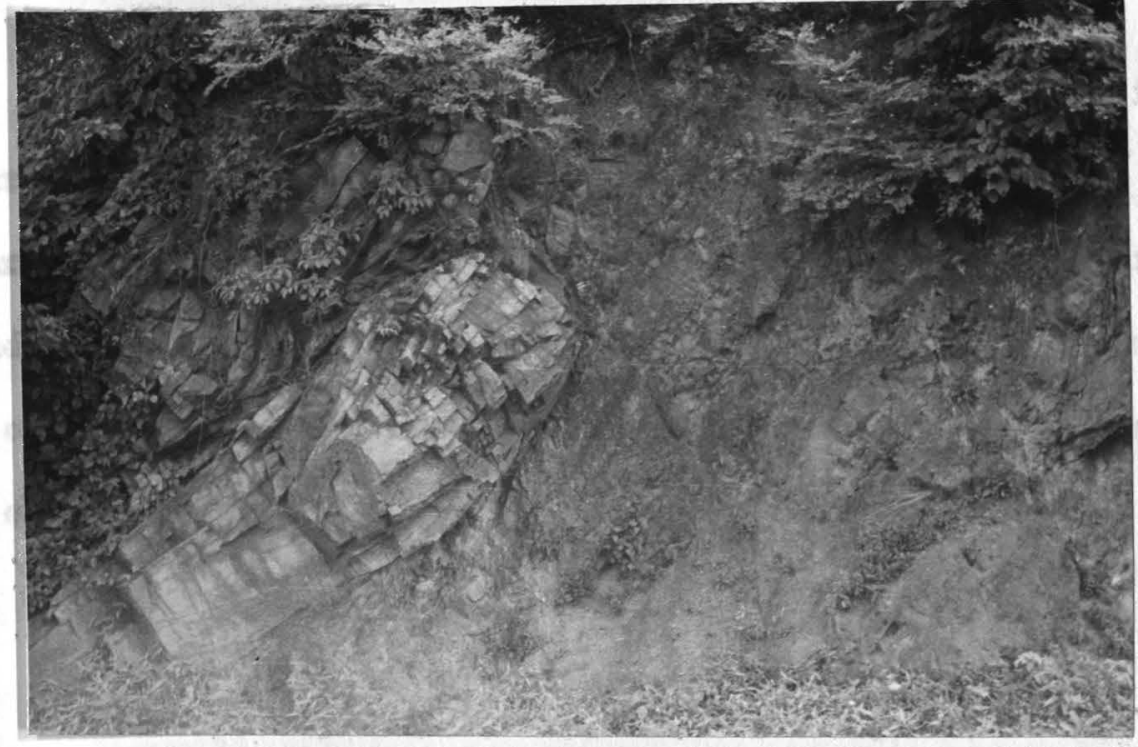

Fig. 17. Roll-bottom greenish-gray sandstone resting upon red shale. Catskill formation one mile north of the Newport bridge along U.S. Routes 22 and 322.

The upper 400 feet of the Catskill formation contains medium- to thick-bedded grayish-green highly micaceous quartz sandstone. It is cross-bedded and contains both angular fragments of red shales and a few quartz fragments up to threefourths of an inch in diameter. Red shales are interbedded with the sandstones but do not constitute as great a thickness. This appears to be the Honeysdale sandstone member named by $I . C$. White (Wilmouth, p. 975, 1938). This sandstone was recognized by Bradford Willard in an exposure along the north flank of Peters Mountain, seven miles south of the Millerstown quadrangle (Willard, et. al., pp. 288-291, 1939).

No fossils were found in the Catskill formation during this investigation. Claypole (pp. 72-78, 1885) reports fossils from the lower portion of the formation. These include plant remains in the olive-green sandstones and fish scales from the red shales. 
The topographic expression of the Catskill formation is similar to that produced by the Portage, although the ridges are neither as high nor as steep. East of the Juniata the Catskill red beds crop out in a wide belt north of Buffalo Mountain and again sonth of Berry Mountain. West of the river the Catskill formation crops out along the axis of the Millersburg synclite. .

\section{MISSISSIPPIAN SYSTEM}

The Mississippian is the youngest system encountered in this area. The overlying Pennsylvanian has been removed by erosion and the nearest strata of that age crop out about fifteen miles east of the Millerstown quadrangle. The Mississippian in south-central Pennsylvania comprises the Pocono sandstone and the Mauch Chunk shale. These two units are ranked as formations in this report (Figure 12). Neither the Loyalhanna formation nor the Greenbrier Iimestone, present in western Pennsylvania, West Virginia, and Maryland, has been identified in this area. The Pocono formation was deposited during early Mississippian time and the Mauch Chunk during late Mississippian time. Due to a lack of fossil remains in these non-marine sediments, their equivalent ages cannot be accurately determined. The entire Pocono and lower portion of the Mauch Chunk crop out in the Millerstown quadrangle. The total thickness of these rocks is estimated to be 4000 feet.

\section{POCONO FORMATION}

A nearly complete unweathered section of the Pocono formations is exposed along U. S. Route 11 south of Mt. Patrick. This is about one mile east of the Millerstown quadrangle. The thickness of 
the Pocono at this exposure was found to be about 1950 feet. The Pocono formation consists of thick-bedded bluish-gray sandstone and conglomerate. Red shales and reddish-gray sandstonos recur at intervals in the lower half of the formation. The gray sandstone and conglomerate often acquire a red coating due to weathering. The conglomerate contains rounded quartz pebbles up to a half inch in diameter (Figure 18). Some coarse sandstone beds contain reworked red and gray shale fragments. In the upper portion of the Pocono are a few thin beds of black carbonaceous shale and impure coal (Figure 19). The only fossils found in the Pocono are carbonaceous plant impressions found in the thin black shale zones. A few feet above the carbonaceous seam shown in Figure 19 is a carbonaceous bed underlain by one foot of bluish-white phosphatic clay. Both of these beds have been opened in a futile search for coal.

The Pocono is a prominent ridge former in south-central Pennsylvania, second only to the Tuscarora formation of lower Silurian age. In the Millerstown quadrangle it caps both Buffalo and Berry Mountains. The slopes of these mountains are covered with much loose float rock from the Pocono formation. Few natural exposures may be seen, although the Pocono has been partly exposed in both sides of Mitchell Gap. 


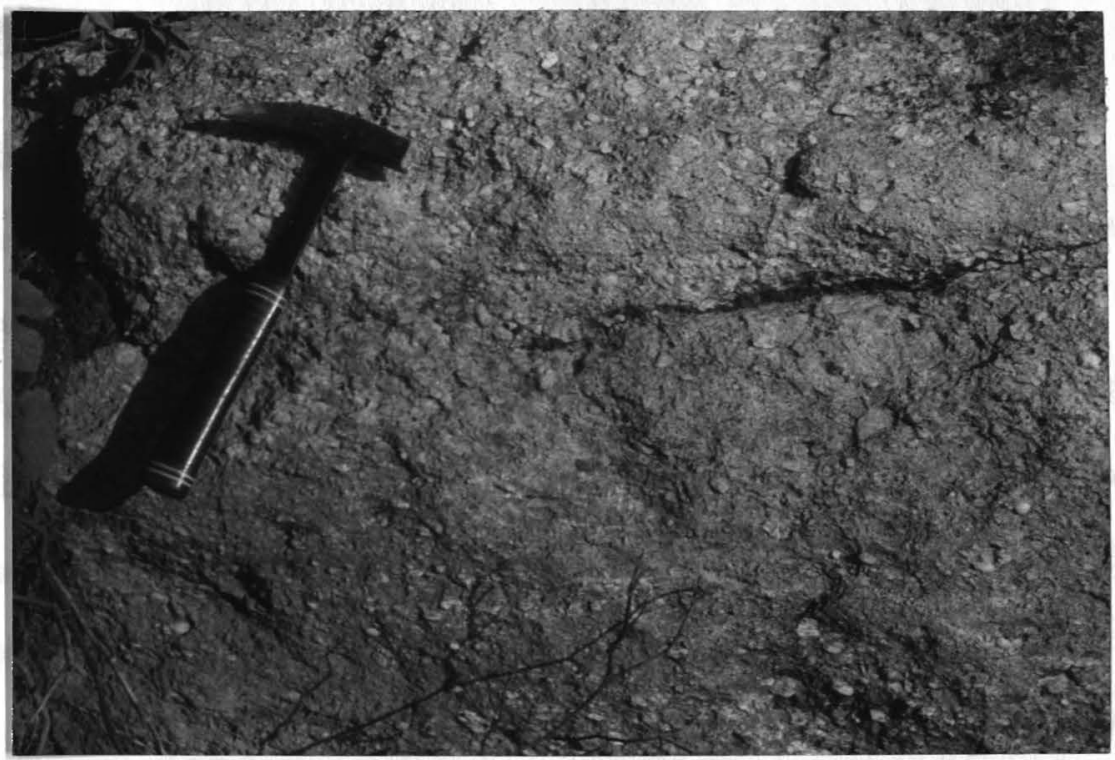

Fig. 18. Weathered surface of Pocono quartz-pebble conglomerate. Photo taken in Mitchell Gap.

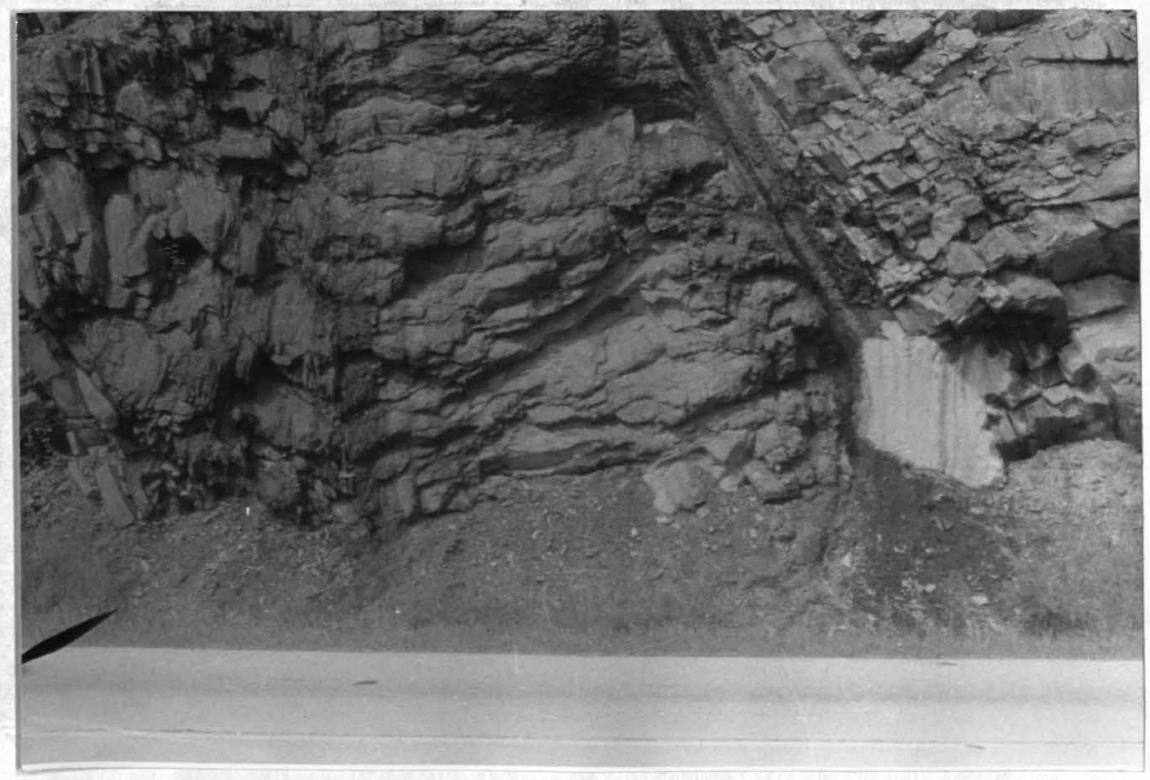

Fig. 19. Impure coal and carbonaceous shale near top of Pocono formation. Faulting against the bed has badly sheared the soft coaly material. Hammer at lower left lies parallel to vertically bedded footwall. Plant fossils were found in thin black shales marked by hammer. 


\section{MAECH CBUNR FORMATION}

The Mauch Chunk formation crops out in the synclinal

Hunters Valley between Buffalo and Berry Mountains. The Mauch Chunk is a relatively weak formation and always a valley maker. In Hunters Valley the Mauch Chunk is so complexly folded and faulted that the thickness could not be determined. The total thickness of the Mauch Chunk is estimated to be about 3000 feet. The distorted beds underlying Hunters Valley probably contain less than 2000 feet of strata. The top of the Mauch Chunk formation has been removed and the nearest complete thickness is fifteen miles east of the area mapped.

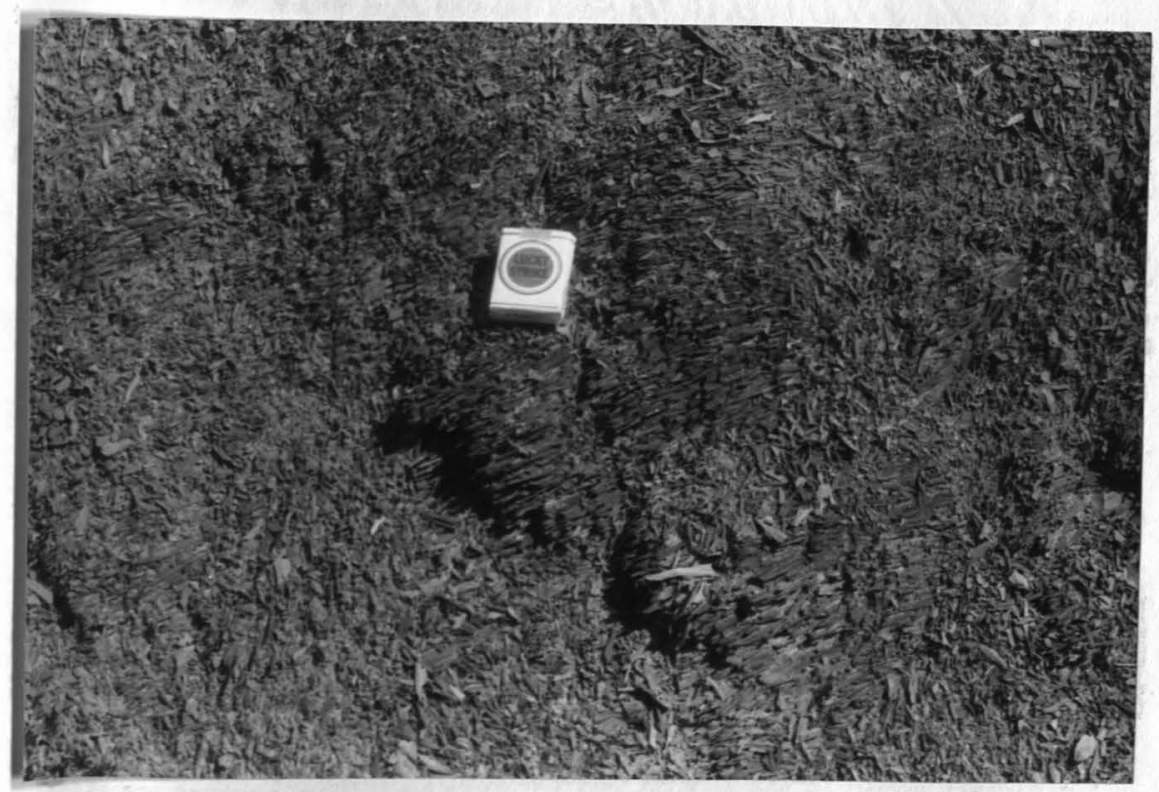

Fig. 20. Brick-red Mauch Chunk shale weathering into splintery fragments. Photo taken in Hunters Valley one mile west of Mt. Patrick.

The Mauch Chunk consists largely of dark-red or grayishred shale with a lesser amount of greenish-gray shale and sandstone. 
The red shales weather readily into platy, splintery, and hackly fragments (Figure 20). The greenish-gray sandstones are fine- to medium-grained and sometimes finely laminated.

Non-calcareous ellipsoidal shale concretions are exposed near the base of the Mauch Chunk. The concretions appear to have formed by cementation of the pre-existing shale with siderite. The steeply dipping bedding planes do not bend around the concretions. The concretions weather by a process of exfoliation. Thin concentric Iayers or spalls split off the outer surface forming curved fragments. The centers contained no visible nuclei but were rich in siderite (Figure 21).

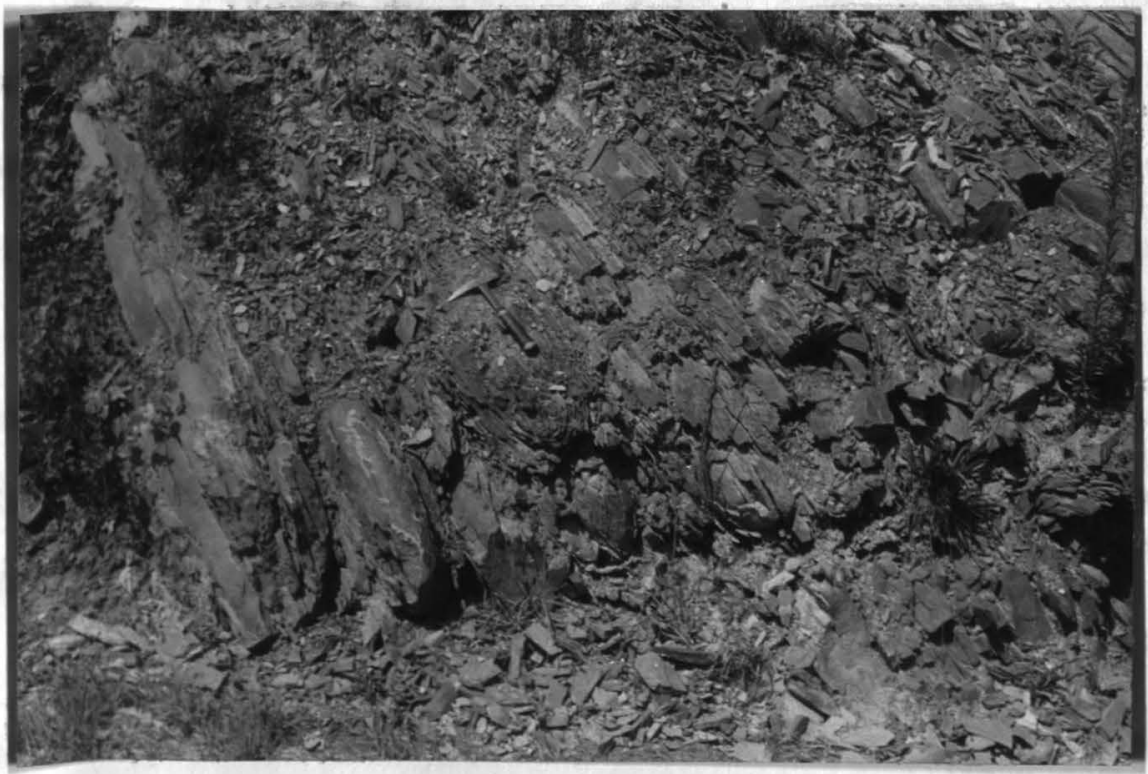

Fig. 21. Siderite concretions weathering from thin-laminated red and green shales. Base of Mauch Chunk formation near Mt. Patrick in the Millersburg quadrangle. 


\section{STRUCTURAL GEOLOGY}

In the area of this investigation the outcropping strata, which are of Silurian, Devonian, and Mississippian age, were intensely folded during the latter stages of the Paleozoic era. This folding which characterizes the Valley and Ridge province, was caused by stresses in general from the southeast. The structural trend is approximately $N 70^{\circ} \mathrm{E}$ with the anticlines and synclines roughly symmetrical. This indicates the direction of active stress was along the $\mathrm{N} 20^{\circ} \mathrm{W}-\mathrm{S} 20^{\circ} \mathrm{E}$ axis. Both to the north and to the south the structural trend within the Valley and Ridge province assumes a more nearly northeast-southwest direction, which is generalIy about N $30^{\circ} \mathrm{E}$.

The Millerstown quadrangle is on a line between Harrisburg and Williamsport, Pennsylvania. This is a distance of eighty miles and represents the maximum width of the Valley and Ridge province. The folded strata within this belt, if flattened out, would expand this width approximately two times (Fenneman, pp. 195, 1938). In general the structure within the area mapped is composed of anticlines and synclines with regional plunge to the east of approximately three degrees (Claypole, 1885).

The structures south of Turkey Ridge are well defined and relatively simple. In that area the stronger more competent rocks of the Tuscarora, Hamilton, and Pocono formations control the nature of folding in the weaker more plastic beds. Although the more conformable beds show local crumpling and even faulting, the over-all attitude of these sediments is similar to that of the sandstones which enclose them. 
North of Turkey Ridge the folding becomes more complex.

There even the Hamilton sandstones have been closely folded and in places faulted. The middle and upper Devonian shales and sandstones have been compressed into a series of complex folds not always clearly indicated by the topographic expression. The northeast portion of the area is further complicated by the presence of a structure plunging to the west.

Some anomalous stratigraphic features of the area, as compared with those bordering 1t, may be related to a major paleotectonic trend. In a recent publication by Herbert P. Woodward (1957), the presence of a buried arch of early Paleozoic age is discussed as follows:

"It is desirable to preface the main theme of this discussion by calling attention to the buried AdirondackHarrisburg arch or axis, the existence of which has only recently been understood and the importance of which has previously been overlooked. This arch was a positive early Paleozoic axis of uplift that extended southward from the Adirondack dome. Its postulated course takes it roughly in a straight line from Cedarville, Herkimer County, New York into the northeast corner of Pennsylvania, whence it is believed to pass west of the northern anthracite basin toward Harrisburg, and thence -- at least during early Devonian time -- into the South Mountain anticline which is the north extremity of the Blue Ridge.

"The Ordovician presence of this axis is abundant1y manifest by stratigraphic differences in rocks on either side of the arch, and various authors, particularly Marshall Kay, have called attention to its existence. It is more plainly revealed, however, by its effect on the Oriskany sandstone, which is absent in the two places where its present outcrop crosses the line of the arch in east-central New York and in the Harrisburg region of Pennsylvania. A number of deep exploratory wells have recently been drilled along the axis between these two points and in each of these wells there was no Oriskany sandstone, although the sand is present in normal thickness in wells drilled 10-12 miles on opposite sides of the arch.

"The structure seems not to have exerted any major stratigraphic control after the mid-Devorian and it has no present structural or topographic expression at the 
surface. Yet its burried presence is substantially established, and its probable action as a concealed buttrese affects the interpretation of other structures. that are better known."

The area studied in this report is just east of the postulated position of the Adirondack-Harrisburg axis. The lack of Oriskany sandstone in the outcrop belt wrapping around the Tuscarora anticline (see geologic map) is evidence to support the presence of this buried structure.

However, an exposure showing six feet of Oriskany sandstone was observed by the writer approximately one mile southwest of East Salem. This is on the western border of the quadrangle, and some distance west of the postulated arch. Where Cocolamus Creek has cut a gap in Turkey Ridge about four and one-half miles east of East Salem, only a small amount of sandy chert occurs in the uppermost chert beds. No bedded Oriskany sandstone was seen in the outerop belt of Oriskany age chert which wraps around the Tuscarora anticline, although the chert can be traced to the eastern boundary of the quadrangle with no appreciable change in thickness.

In reports of the First Geological Survey of Pennsylvania, a system of roman numerals was used to designate the anticlines and synclines. In the Second Geological Survey reports by G. W. Claypole and E. V. d'Invilliers, names were given to the major structures. These names are used in this report unless they appear changed in later Pennsylvania Survey publications.

The structures will be described separately starting with the southernmost fold. 


\section{Millersburg Syncline}

This well defined syncline is the western extension of the Wiconisco anthracite coal basin. Its axis enters the quadrangle just south of the center of Hunters Valley striking N $74^{\circ} \mathrm{B}$, and extends to the border eight miles to the southwest. It is the Berry Mountain syncline described by E. W. Claypole in the Perry County report of 1885. The more appropriate term, Millersburg symeline, was later used by Bradford Willard (Dauphin to Sunbury, 1939). Two miles east of the quadrangle the axis passes through the borough of Millersburg, Dauphin County, and continues eastward as a major synclinal axis for a distance of thirty-five miles. From the point where the axis leaves the southern edge of the quadrangle, it has been traced for another thirty-five miles to the west, making the total length approximately seventy-eight miles.

Hunters Valley, which is a synclinal valley, is underlain by the soft red shales and sandstones of the Mauch Chunk formation. Buffalo and Berry Mountains, which form the slopes of Hunters Valley on either side of the synclinal axis, are capped by the resistant Pocono sandstones.

In Berry Mountain, forming the southern flank, the rocks dip $65^{\circ}-70^{\circ} \mathrm{N} 13^{\circ}$ W. This is also the north flank of the Half Falls Mountain anticline, of which the eastward plunging axis lies outside of the Millerstown quadrangle and three miles south of Berry Mountain. The strata of the north flank of the Millersburg syncline have less dip than those of the southern flank. The sandstones in Buffalo Mountain have the approximate attitude $55^{\circ}-60^{\circ} \mathrm{s} 20^{\circ} \mathrm{B}$. 
The Catskill red beds crop out around the western nose formed by the junction of Buffalo and Berry Mountains. Near the axis west of the Juniata, these beds have gentle dips but north of Buffalo Mountain, along the eastern boundary of the quadrangle, they are nearly vertical. Outside the area of this quadrangle older formations successively wrap around to the west, while in the direction of plunge, younger formations occur.

A small anticline within the Pocono formation at the eastern end of Buffalo Mountain has resulted in a split in an otherwise very straight and even mountain crest. The flexure probably extended some distance across the gap now occupied by the Susquahanna River. It may have been a factor in the location of the gap of this point. The structurally concordant ravine formed in the end of this mountain occupies the position of a small syncline (Figure 22).

On the north side of Berry Mountain a very distinct ridge juts from the otherwise straight and steep slope. This is due to a sharp east-west trending fold in the Pocono formation. As the anticline passes into the soft shales of the Mauch Chunk formation it becomes indistinct.

The soft red shales and sandstones underlying Hunters Valley show evidence of much crumpling and faulting. These disturbed beds dip generally toward the synclinal axis, although variable dips indicating the presence of minor structures were taken on exposures just east of the Millerstown quadrangle. 


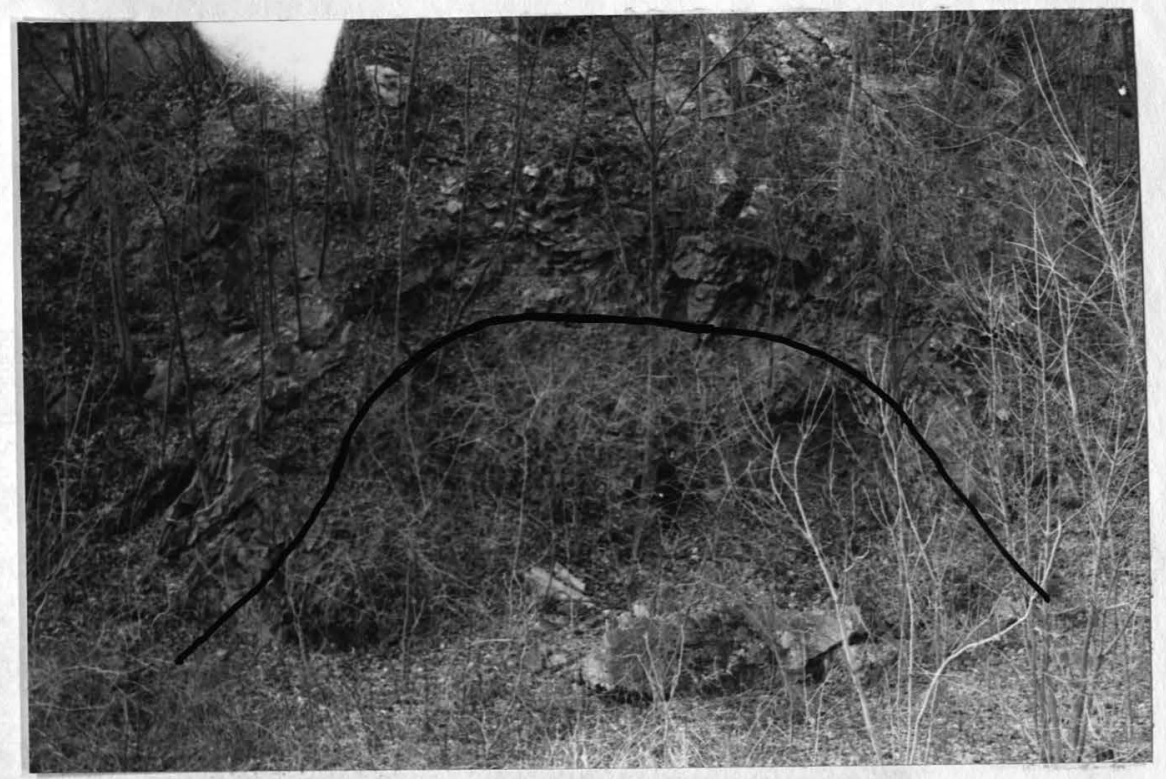

Fig. 22. Arch exposed in Pocono sandstone.

East end of Buffalo Mountain.

Tuscarora Anticline

The north flank of the Millersburg syncline forms the south flank of another major structure, the Tuscarora anticline. The axis of the anticline extends across the quadrangle from east to west and is easily followed on the topographic map (see geologic map in appendix). To the southwest it extends along the crest of Tuscarora Mountain for twenty-three miles (Claypole, 1885). Eastward the axis lies in Pfoutz Valley between Wildcat and Turkey Ridges and extends to the Susquehanna River, a distance of twelve miles.

In the Millerstown quadrangle this structure is nearly symmetrical. The strike is $\mathrm{N} 68^{\circ} \mathrm{E}$ in the western half of the quadrangle and $\mathrm{N} 79^{\circ} \mathrm{E}$ in the eastern portion. The dips on the flanks of Tuscarora Mountain are about $30^{\circ}$ on the south slope and $25^{\circ}$ on the north. Away from the axis these dips become steeper, being $50^{\circ}$ in 


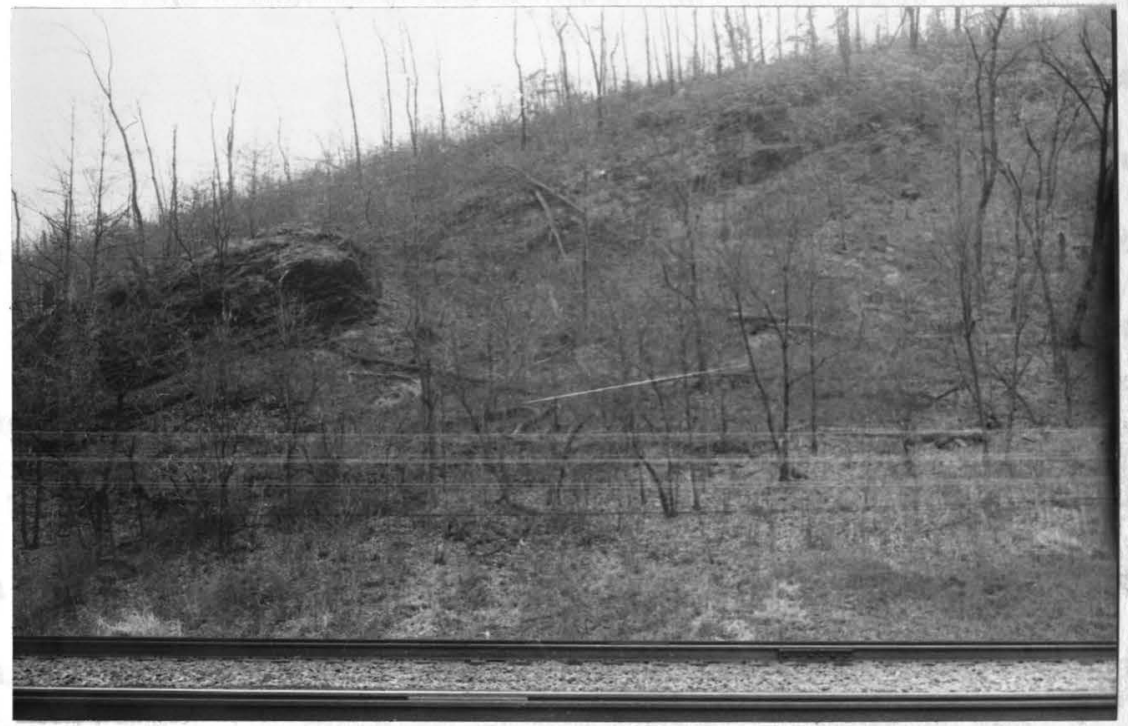

Fig. 23. South flank of Tuscarora Mountain at Juniata River gap. Tuscarora sandstone forms dip slope.

Raccoon Ridge on the south flank and $45^{\circ}$ in Turkey Ridge on the north flank.

The Tuscarora anticline in the area of Millerstown quadrangle is plunging to the east about $3^{\circ}$. This fold, being controlled by the very strong Tuscarora formation, forms a nearly straight line throughout its length. The Upper Silurian rocks, although consisting largely of weak shaly beds, show little evidence of crumbling or faulting. Further from the axis the Devonian rocks have in places been more complexly folded. The western portion of Wildcat Ridge contains a flexure within the middle and upper Devonian formations. This has offset the eastern end of Wildcat Ridge a little to the north of its eastern continuation, west of the Juniata River, as Raccoon Ridge (see geologic map in appendix). 
The Tuscarora anticline splits for a short distance as it passes through Pfoutz Valley in the plunge area of the weaker Silurian strata. There the weak shales and limestones have been folded to form two anticlines (see geologic map and cross sections in apendix).

South of Thompsontown the Bloomsburg formation underlies an abnormally wide area. This indicates the presence of folding or faulting to give a repetition of the Bloomsburg formation. Dre to a lack of sufficient outcrops the underlying structure could not be fully determined. The bedrock south of Thompsontown, along the Juniate, is covered by thick alluvial deposits.

\section{Tuscarora Syncline}

The fold Inmediately north of Tuscarora Mountain was naned Tuscarora syncline by E. V. d'Invilliers in the Juniata County regort. The position of the syncline east of Delaware Greek was not indicated on the geologic map accompanying the report.

This syncline bifurcates into two with an intervening sald anticline and shows evidence of faulting in the Delaware Creek section. It is not well defined to the east but appears to be contimuons with the syncline which follows Dutchman Run and extends farther esst passing to the north of the Dalmatia anticline.

\section{Academia Anticlime}

The Academia anticline, which separates to form two anticlines where it crosses Delaware Creek, was named by E. $\nabla$. d Invilliers (1891) for a borough of that name located fourteen miles west of Thompsontown. 
This is the eastern plunge area of the anticline and it becomes indistinguishable not far from the point where it leaves the north border of the mapped area.

The Wills Creek shales are the oldest rocks at the surface along this anticline in the area studied. Shellys Ridge, formed by the arched Hamilton sandstone, is a topographic expression of the Academia anticline.

\section{East Salem Syncline}

This nearly symmetrical syncline, named for the small borough on : Delaware Greek ( E. V. d'Invilliers, 1891), crosses the northwest portion of the map trending $N 70^{\circ} \mathrm{E}$. The axis in upper Devonian shales and sandstones plunges to the east. The ridge-forming Montebello sandstones flank the axis with dips of $40-45^{\circ}$.

In the extreme northwest corner of the area is an anticlinal axis. The Keyser limestone crops out along the axis and the underlying Tonoloway limestone has been exposed by recent quarrying operations. This is probably an eastern extension of the Blacklog Mountain anticline (E. V. d'Invilliers, 1891).

\section{Structures North of Pfoutz Valley}

In the northeast section of the area an anticline is developed on the north flank of the Tuscarora anticlinorium in the Hamilton formation. This fold is most prominent to the east and dies out to the west. The anticlinal axis is separated from the main Tuscaror 
axis, on the south, by a small syncline. North of the anticline is another syncline, the axis of which lies in the Portage shales along Dobson Run. The axis strikes almost east-west and can be followed to the Cocolamus Creek gap north of Wardville where it is cut by a fault zone in the Hamilton sandstone. West of Cocolamus Creek the syncline is less well defined and cannot be mapped with certainty.

\section{Dalmatia Anticline}

This was the Georgetown anticline described in the Second Pennsylvania Survey report (E. V. d'Invilliers, 1891). The borough of Georgetown was later changed to Dalmatia which led to changing the name of the anticline.

This is the only major structure in the area which plunges to the west. The axis strikes $N 70^{\circ}-80^{\circ} \mathrm{E}$ and dies out west of Cocolamus Creek. The dips are $20-30^{\circ}$ on both flanks in the Cocolamus Creek section and east of Seven Stars. South of Seven Stars the axis is domed up so as to expose the Hamilton formation at the surface. The Hamilton formation is again exposed along the axis northeast of the mapped area. 


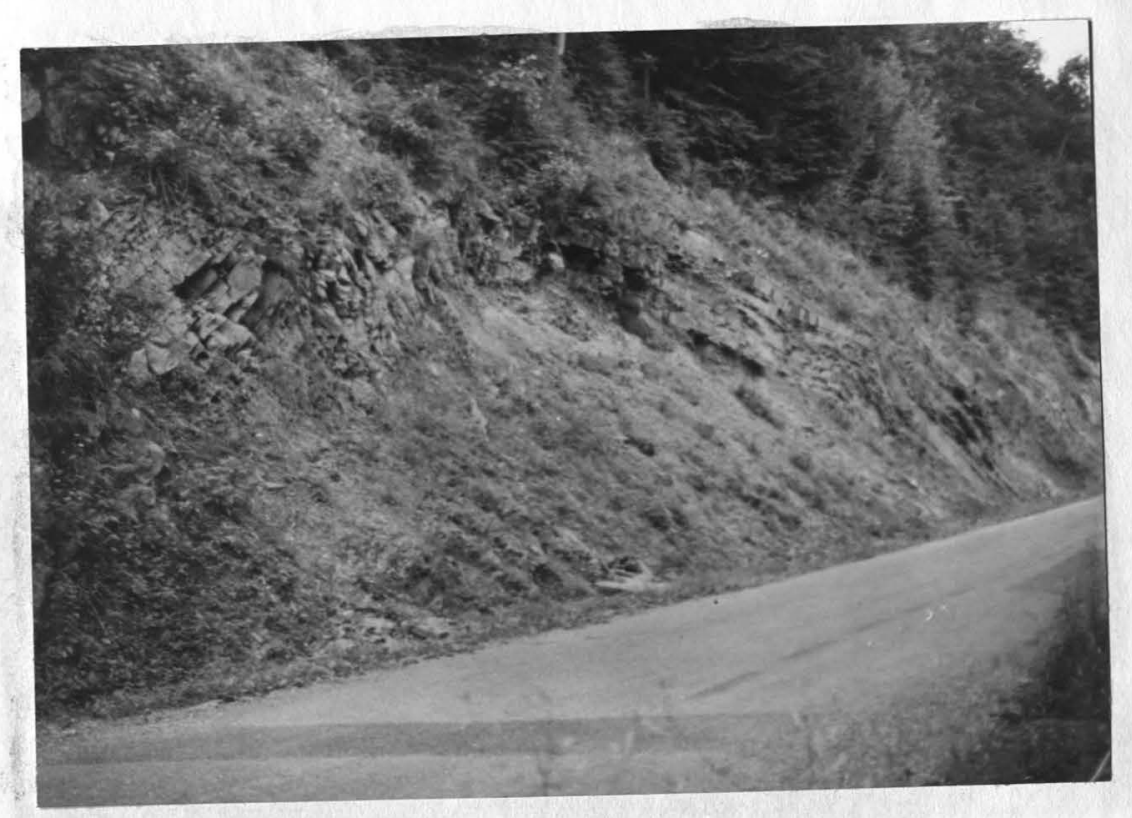

Fig. 24. This arch, exposed along the road one mile north of Wardville, marks the axis of a westward plunging continuation of the Dalmatia anticline.

Faults

An excellent exposure of faulted strata may be seen in a road cut along Delaware Creek in Juniata County. This cut is on the east side of Pennsylvania Route 135, one-half mile north of Thompsontown. There the Hamilton sandstones dip steeply to the south, as do the fault surfaces. The two most evident fault surfaces dip at angles of $25^{\circ}$ and $40^{\circ} \mathrm{S} 15^{\circ} \mathrm{E}$. (Figures 25 and 26). In the north end of this exposure the rocks are severely broken, and neither bedding planes nor fault planes can be distinguished. The beds on the south have been overthrust upon the beds north of the fault zone. The fault planes are parallel to the strike of the bedding. No measurement could be obtained on the amount of throw involved but it appears to be less than the thickness of the Hamilton sandstone. . 


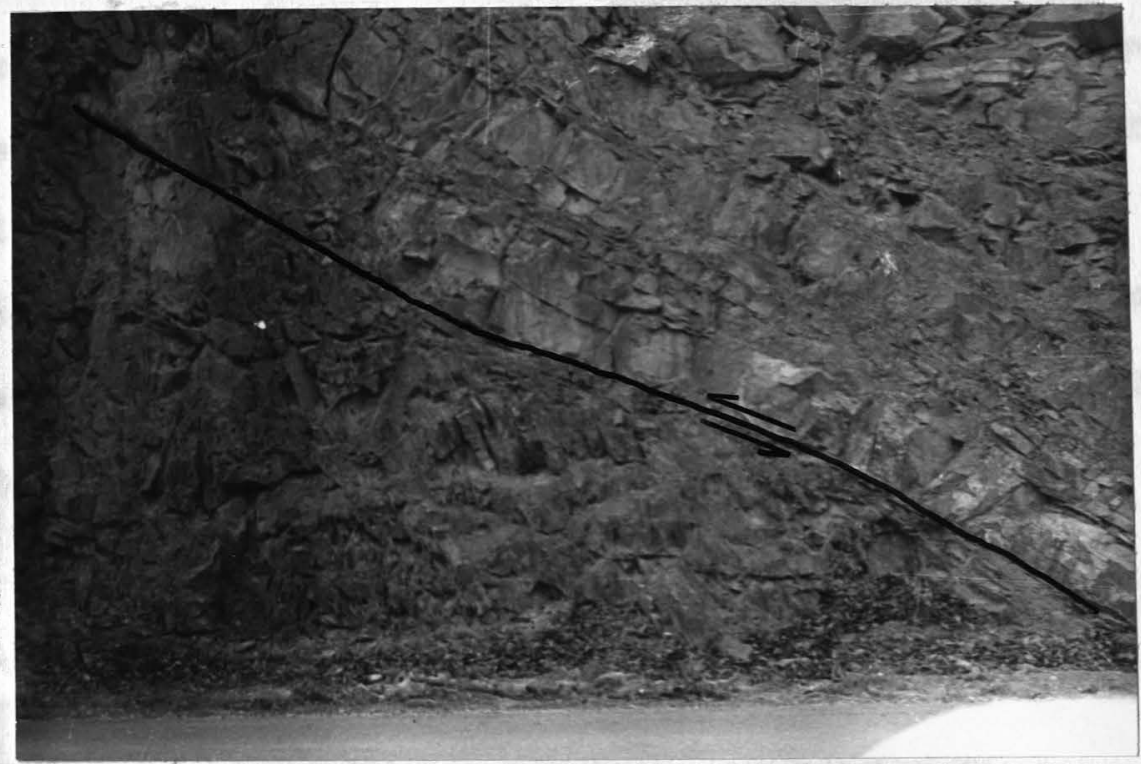

Fig. 25. Hanging wall is upthrown side of fault. Beds in footwall show some drag faulting. Photo taken one-half mile north of Thompsontown.

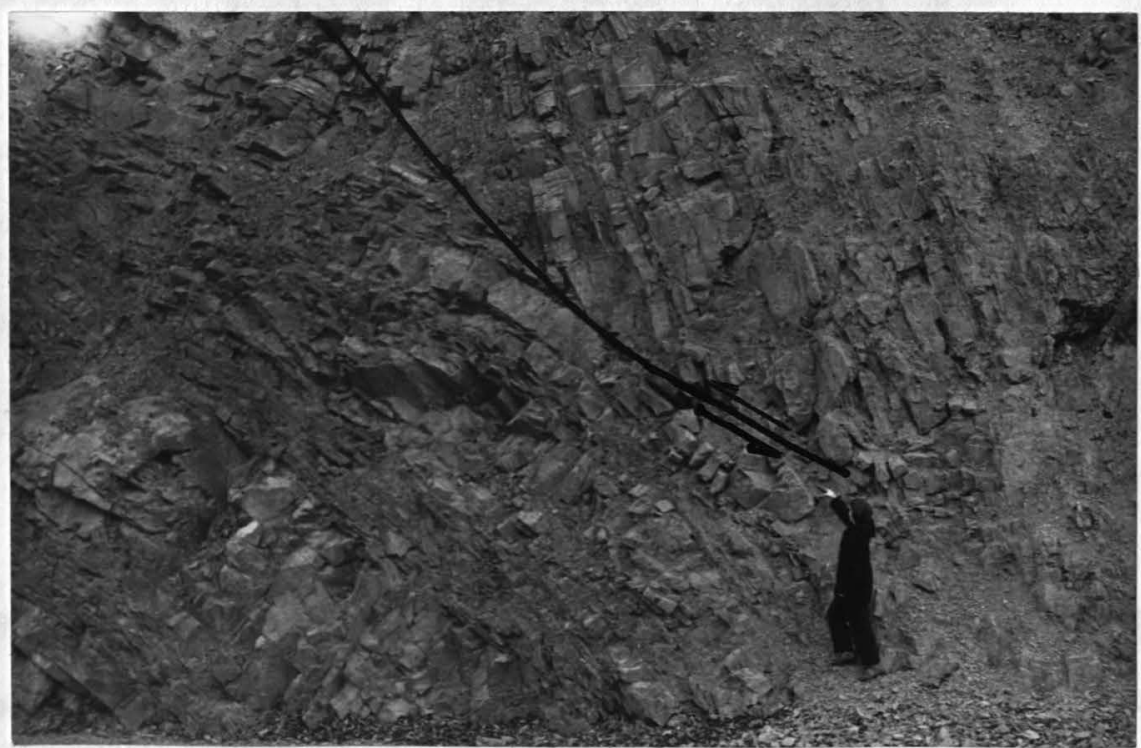

Fig. 26. Fault surface exposed a short distance north of Figure 25. Hanging wall thrust over footwall. 
Five miles east there is a fault zone along the west bank of Cocolamus Creek, half a mile north of Wardville. Although partly covered, three nearly vertical strike faults may be seen cutting the Hamilton sandstones. The stratigraphic throw could not be determined as there are similar-appearing Hamilton age sandstones on both sides of the fault zone (figure 27). This is probably a continuation of the fault zone exposed along Delaware Creek.

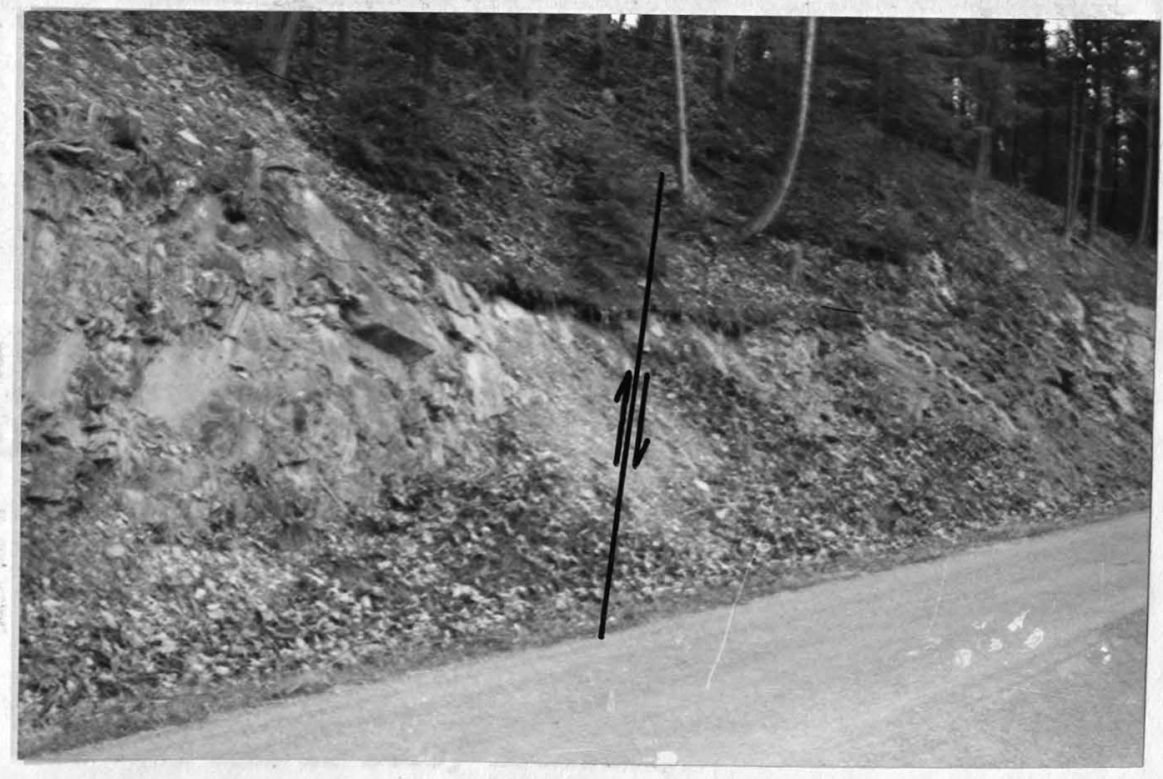

Fig. 27. Fault is covered due to weakness of broken rock along fault surface. Beds to right of fault are dipping north, those to the left are dipping south. Half a mile north of Wardville.

In Hunters Valley near the Susquehanna River and just south of Buffalo Mountain, there is a low angle thrust fault in Mauch Chunk red shales and sandstones. The fault dips about $20^{\circ} \mathrm{s}$ as does the bedding of the hanging wall. These beds have been thrust over the beds of the footwall which dip $80^{\circ} \mathrm{s}$. 
Along U. S. Route 11, ore mile north of Montgomery Ferry In the Millersburg quadrangle, a fault zone is well exposed. The beds dip $70^{\circ}-80^{\circ} \mathrm{N} 10^{\circ} \mathrm{W}$ and the fault planes are nearly parallel to the bedding (Figure 28). Between the two faults, only fifteen feet apart, the beds are greatly contorted and broken.

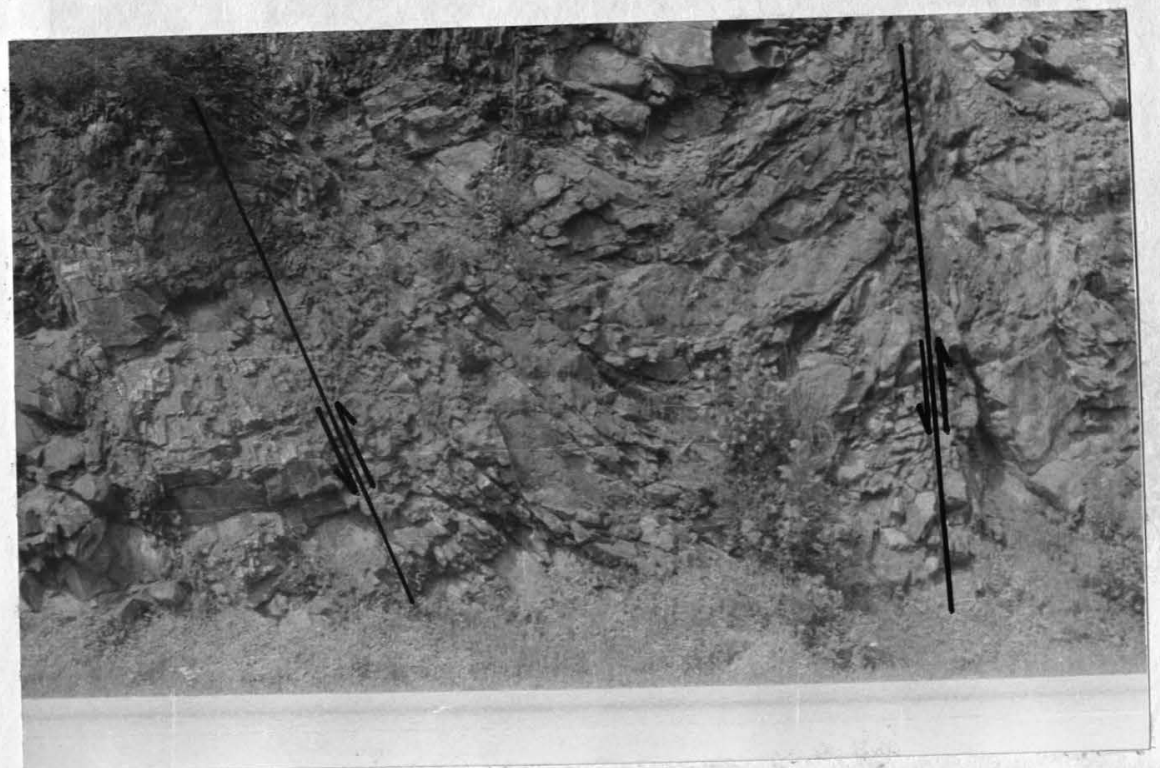

Fig. 28. Faulted sandstone and shales near the Catskil1-Pocono contact in the road cut in east end of Berry Mountain.

Other faults may be seen nearby in this exposure (Figure 19). Some are marked by thick layers of fault breccia and fault gouge.

\section{Shear Fractures}

Shear fractures associated with faulting are well developed in the exposure along the east end of Berry Mountain. At that locality the soft red continental type shales are interbedded with 
massive hard basal Pocono sandstones. Figure 29 shows a fault plane parallel to the bedding with shear fractures developed in the shales adjacent to the fault surface.

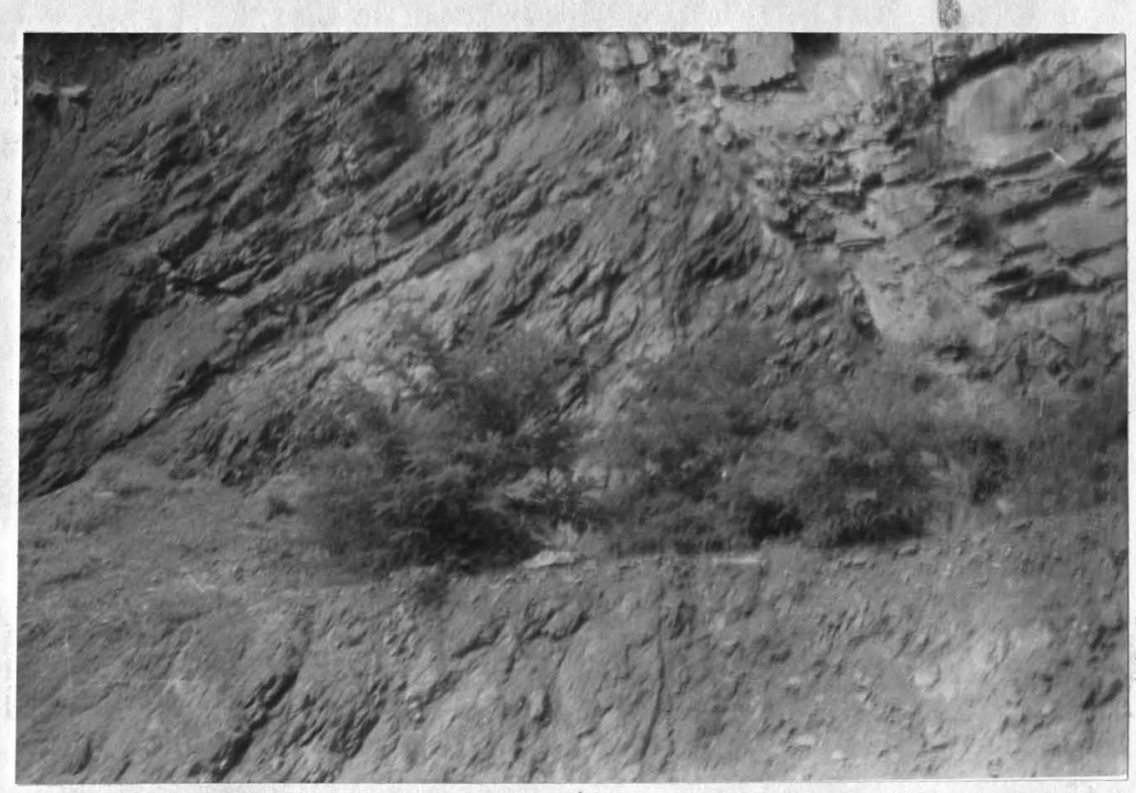

Fig. 29. Shear fractures developed in shales adjacent to fault surface. Bedding on both sides of fault dips steeply to the right. East end of Berry Mountain.

\section{Joints}

Jointing is developed in most if not all rocks of this area. No study was made of the regional joint patterns but they were no doubt formed by the same forces which folded and faulted the sediments. Figures 30 and 31 illustrate jointing in two types of 1ithologies. 


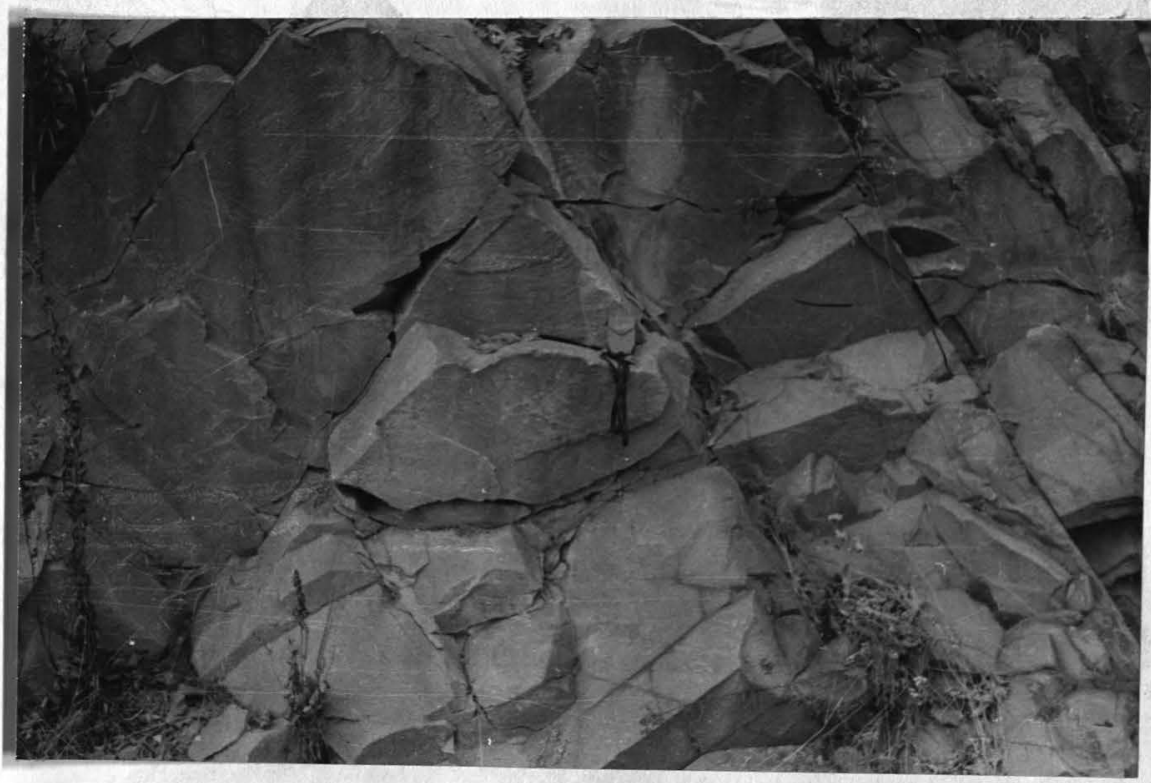

Fig. 30. Block-jointed Hamilton sandstone. The bedding dips $60^{\circ}$ to the right. Respective joint sets are vertical and dip to the left. Some joints filled with travertine.

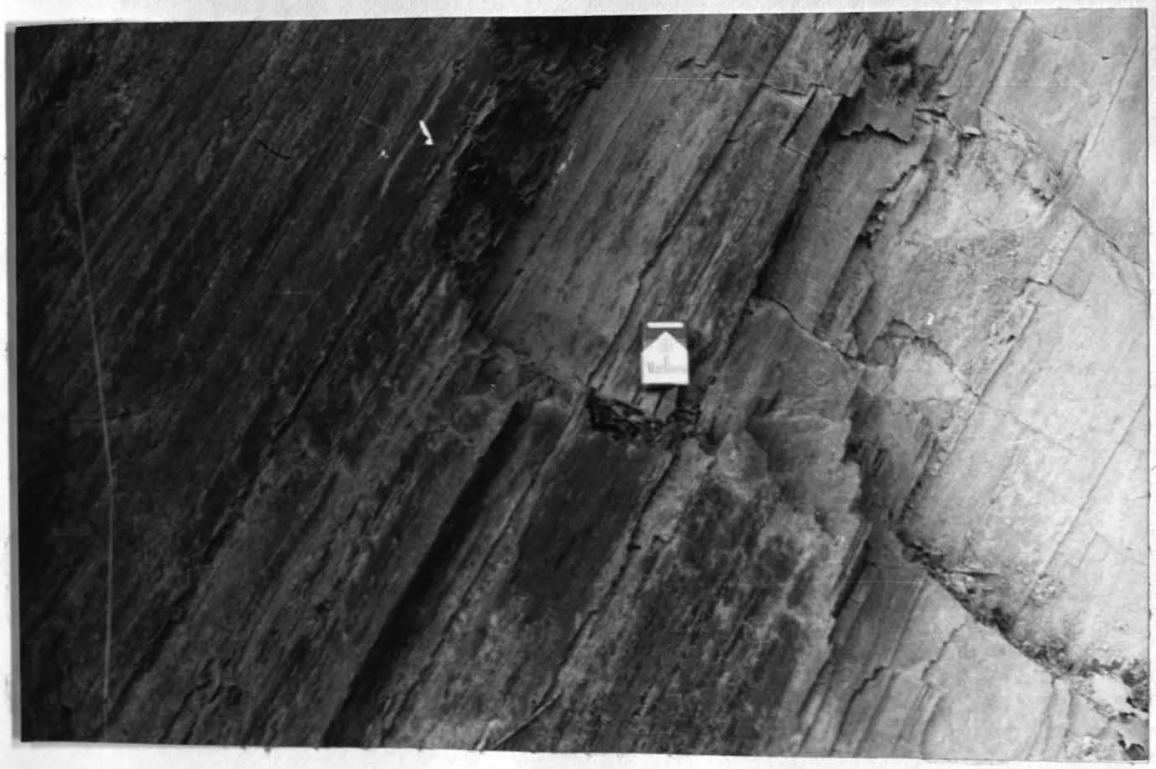

Fig. 31. Marcellus black fissile shale dipping $60^{\circ}$ to the left. Joint planes are well developed vertically and imperfectly developed dipping to the right. 


\section{Slickensides}

Slickensides are formed on the walls in contact along some fault surfaces. Friction between the moving walls form a system of parallel groves with interspersed ridges. Figure 32 shows this feature in a block of Hamilton sandstone.

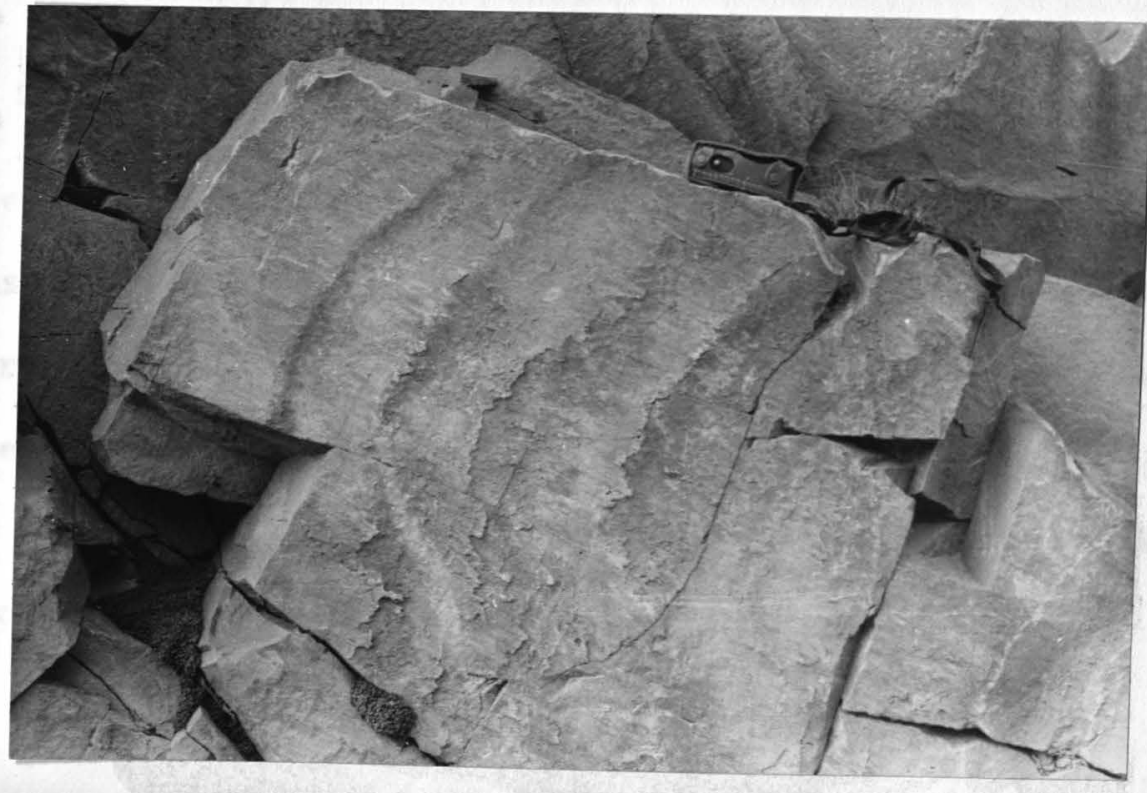

Fig. 32. Slickensides formed on fault surface in a block of Hamilton sandstone. The opposing face moved from left to right relative to the face shown. Striations parallel to the direction of movement are barely visible in photo. 
GEOMORPHOLOGY

This area lies wholly within the Appalachian Valley and Ridge province. It is in the mature stage of the geomorphic cycle of erosion. The topographic expression is in most cases a reflection of the underlying structure. The strike of these structures is N $70-80^{\circ} \mathrm{E}$, and most folds plunge gently to the east.

The higher ridges represent the Schooley (Kittatinny) Peneplain or erosion surface. This is the only clearly defined erosion surface present. Erosion surfaces at altitudes Lower than the Schooley 1.e. Harrisburg, which have sometimes been called peneplains, are now believed to be best described as straths (Fridley, 1957). The Schooley Peneplain is thought to have been formed during Tertiary time, probably Miocene or early Pliocene (Ashley, 1930).

\section{Topography}

The highest elevation is the crest of Tuscarora Mountain where it leaves the western border of the area. The altitude there is 1740 feet. The lowest point is the level of the Juniata River where it crosses the southern edge of the Quadrangle. The altitude there is 373 feet, resulting in a maximum relief for the area of 1367 feet. Most of the ridges are hogbacks. Exceptions are Tuscarora Mountain, Slaughterback Hill, and Shellys Ridge, which are anticlinal.

An impressive topographic high is present at the apex of Buffalo and Berry Mountains which are capped by the Pocono formation. 
There the peak has an elevation of 1440 feet and drops steeply 1070 feet to the Juniata River only six-tenths of a mile to the west. This peak is some 200 feet higher than the general level of ridges to the east. This exemplifies a common feature which is often developed at the apex of ridges bordering a plunging syncline or anticline. The apex is higher than the general attitude of the ridges due to a greater thickness of the ridge forming formation (Ver Steeg, p. 152, 1930). Five miles northeast a lower and less distinct knob rises above the Buffalo Mountain erest or Schooley surface. This knob, which has an altitude of 1320 feet is related to a minor syncline also plunging to the east.

Other prominent ridges in the area are those capped by the Montebello sandstone. The crests of these ridges generally have altitudes of about 900 feet. Raccoon, wildcat, and Turkey Ridges are hogbacks, capped by this sandstone, flanking the Tuscarora anticline. Shellys Ridge, also capped by the Montebe1lo sandstone has a maximum altitude of 1029 feet.

The valleys do not have a common level but may be at any altitude between 400 and 600 feet. These different levels of the dissected valley areas appear to be due not to periods of uplift but to the relative resistance of the underlying strata. Most valley areas are underlain by strata dipping in one direction, however, Pfoutz and Hunters Valleys are respectively anticlinal and synclinal.

\section{Drainage}

All the drainage is into either the Juniata or Susquehanna Rivers. The divide is not centered so that the larger area drains 
into the Juniata. Cocolamus Creek is the largest tributary, draining approximately one-third of the area. A large portion of its course is across the structural trend. This course must have been established on a previously peneplaned surface. Delaware Creek, which drains the northwest portion, also flows perpendicular to the structure. Most tributaries to the Juniata or Susquehanna Rivers flow parallel to the structural trend.

\section{Wind Gaps}

A pair of interesting aligned wind gaps are present in the area investigated. Near the apex of Buffalo and Berry Mountains two gaps, known together as Mitchell Gap, have been cut approximately 300 feet below the crests of the ridges (Figure 33-A). It appears that the two gaps were notched out by a former south flowing stream, presumably the Juniata. The stream later abandoned its course at an elevation of about 800 feet and assumed a course around the resistant ridge-forming Pocono formation (Figure 33).

Upon careful inspection of aerial photographs it appears that the gaps may be in part due to structure rather than chance location of a superimposed stream. Buffalo Mountain maintains a very straight crest striking $\mathrm{N} 57^{\circ} \mathrm{E}$, for three miles east of Mitchel1 Gap. The crest west of the gap is also straight but strikes N $72^{\circ} \mathrm{E}$. There is clearly a change of $15^{\circ}$ in strike direction of the crests. This indicates a possible fault zone perpendicular to the strike of the ridges. The southern ridge does not appear to have a change in strike and if faulting is present it is only slightly affected. No real evidence of faulting was found in the field. 
From the southern gap a small stream, called Howe Run, flows in the same general direction for two miles before joining the Juniata, although it is only a half mile from the Juniata where it leaves the gap in Berry Mountain (Figure-33-C). North of Mitchell Gap a tributary to Wildcat Run flows along the same line determined by Howe Run and the two gaps. This line represents the course of the stream which is responsible for forming Mitchell Gap.

\section{Water Gaps}

The course of the Juniata River was established on a nearly peneplaned surface. The Juniata is not adjusted to the underlying structure, and in the Millerstown quadrangle it flows across the structural trend. This has produced eater gaps between Tuscarora Mountain and Slaughterback Hill, and between Raccoon and Wildcat Ridges.

South of Donnally Mills a gap 400 feet deep has been cut through Raccoon Ridge. This gap may have originated from a superimposed stream, although no corresponding aligned gaps have been cut to the north or south. Faulting is a possibility as this would have produced a zone of weakness in the hard sandstone formation capping the ridge. Evidence of this fault was not found during the field investigation.

Just east of the area mapped the Susquehanna River flows through steep walled gaps in Berry and Buffalo Mountains (Figures 33-B and D). These gaps are taken as evidence of superimposition of 
the Susquehanna upon the structure from a former peneplane or Cretaceous covermass. The presence of cretaceous sediments is discussed by D. W. Johnson (1931).

Ver Steeg discusses the lack of a steep lower slope on the west side of the gap between Buffalo and Mahantango Mountains (Figure 33-B). The west slope has a maximum angle of only $30^{\circ}$ at the base and flattens to about $5^{\circ}$ westward. The east slope has an angle of $40^{\circ}$ to $42^{\circ}$ at the base and rises steeply to the east. Ver Steeg states the difference in slope is due to the presence of a small stream flowing eastward from the crest of Buffalo Mountain. "It w111 be observed that a small stream flows down the west slope of the notch in an east-west direction, bisecting the ridge and dividing it into two narrower parts. The rate at which a tilted formation is lowered by erosion depends in part on its thickness and, all other conditions being the same, a narrower ridge is lowered more rapidiy. The presence of the stream therefore, accounts for the lower elevation of the ridge on the west side, and the long continuously convex slope into the upper level." (Ver Steeg, pp. 190-191, 1930). To assume that all other conditions are the same as described above is in error. Evidence obtained in the field indicates that the stream is coincident with the axis of a syncline, and the axis of an anticline is located a short distance south of the stream valley and is coincident with a ridge. (Figure 33 and geologic map in appendix). Therefore the structure of the underlying rock is responsible for the more gentle slope of Buffalo Mountain. 


\section{Stream Piracy}

The Juniata River once flowed through Mitche11 Gap following uplift of the Schooley erosion surface. As it flowed over the hard Pocono sandstone, tributary streams were developing in the softer Catskill formation. One such tributary stream flowed in the approximate course of the present Juniata from the junction of Howe Run (Figure 33-C) northward past Newport and the apex of the Pocono ridges. By headward erosion this stream captured the Juniata River (north of A in Figure 33) and diverted its flow around the resistant Buffalo and Berry Mountains.

An example of probable stream piracy is illustrated near Donnally Mills. Buckwheat Run very likely flowed in an eastern direction between Raccoon and Hominy Ridges, joining the Juniata one mile below Millerstown. Raccoon Creek flowed parallel to Buckwheat Run on the north flank of Raccoon Ridge. Buckwheat Run, flowing in the upper Devonian shales and sandstones was not able to lower its valley as rapidly as Raccoon Creek which was developed in upper Silurian shale and limestone. Tributaries to Raccoon Creek rapidly cut a gap through the Hamilton sandstone, possibly along a zone weakened by faulting. The flow of Buckwheat Run was diverted through the gap into Raccoon Creek, and now drops 70 feet in the short distance through the gap. The portion of its former valley not draining into the gap is occupied by Sugar Rum. The divide separating the two streams has an altitude of 760 feet or 200 feet higher than Buckwheat Run where it now enters the gap. 
Future Capture of the Susquehanna

The Susquehanna River has an altitude of 377 feet just north of Buffalo Mountain (Figure 33-B). The Juniata River is at 373 feet where it passes west of the apex of Buffalo and Berry Mountains. The Juniata is flowing at a lower level and will not have to cut through the very resistant Pocono formation as will the Susquehanna. Consequently, according to Von Engeln, piracy by Wildcat Rum and its tributaries which flow into the Juniata is geomorphically imminent. First the headwaters of Wildcat Creek and later the Susquehanna River will be diverted into the Juniata along the north flank of Buffalo Mountain. At that time the gaps in Buffalo and Berry Mountain now occupied by the Susquehanna will become wind gaps (von Engeln, pp. 225-226, 1942). 


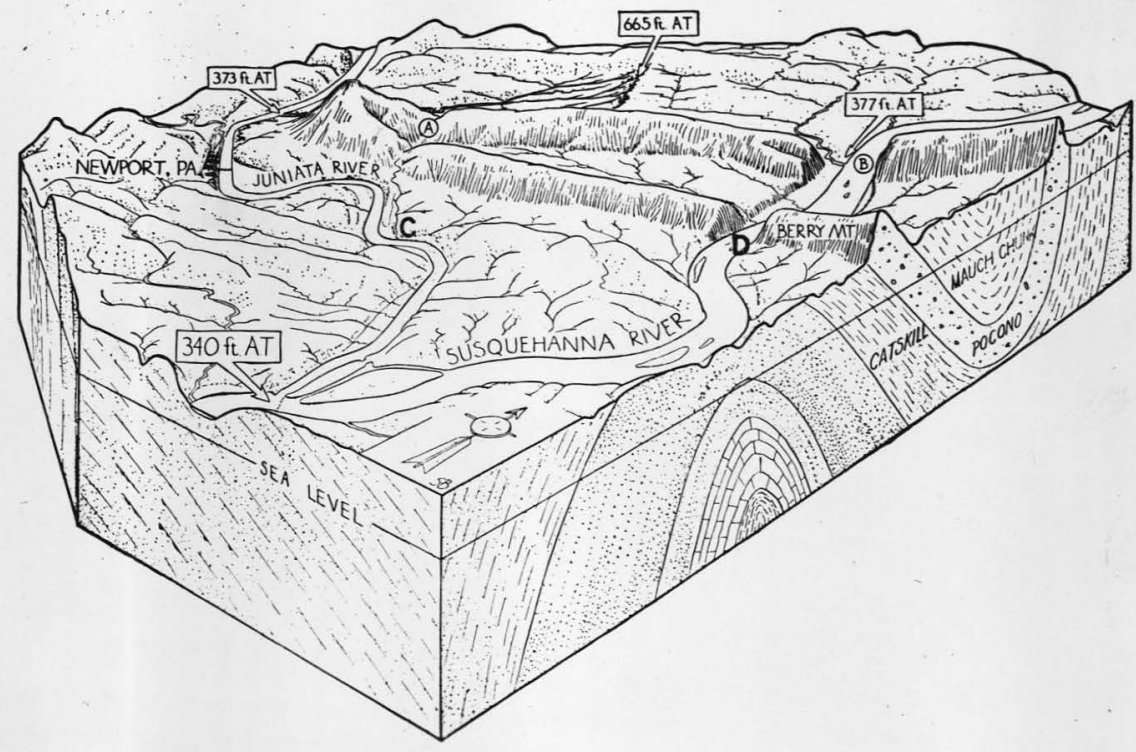

Fig. 33. Wind and Water gaps in Berry and Buffalo Mountains. Drawing by Steve Barker (von Engeln, p. 226, 1942).

(A) Mitche11 Gap

(B) Gap between Buffalo Mountain on the west and Mahantango Mountain on the east.

(C) Junction of Howe Run and the Juniata River.

(D) Gap between east and west segments of Berry Mountain. 


\section{ECONOMIC GEOLOGI}

The natural resources of the area studied are limited both in variety and in value. A single limestone guarry is the only industry utilizing the natural resources other than soil and water. The ecnnomy of the area has in the past been based on farming and this will probably continue to be the main occupation. However, a limited use of local resources has been important in development of the area. Some of the past and possible future uses are described in the following sections.

\section{Agricultural Limestone}

Limestone is abundant in the axea although not always of high quality. At present there are no quarries in operation for agricultural limestone. Scores of small abandoned quarries can be seen throughout the area. Years ago most farmers with limestone on their property, quarried and burned their own limestone and sold small amounts of the resultant lime to neighbors. The limestone was largely from the Helderberg, Keyser, and Tonoloway formations. Limestone also may be found in the Onondaga and McKenzie formations but these beds have not been used in the past. The limestones generally dip steeply beneath the surface and are not favorably situated for large scale operations (B. I. Millex, pp. 444-446, and 616-624, 1934). 


\section{Building Stone}

Local stone has not been extensively used for building purposes. Foundations for houses and barns have been constructed of a great variety of stones. The stone used in most cases was obtained from the nearest source regardless of physical character or quality. Sandstone from the Marcellus and Hamilton formations is available over much of the area and has been used often for foundations and cellar walls. Tuscarora sandstone has been used in the vicinity of its outcrop. Retaining walls along the Pennsylvania Railroad are of this stone, as are the pillars of the Thompsontown bridge. Limestone has been used in a few buildings near the Keyser-Tonoloway outcrop areas. Due to intense folding and close joint patterns there is probably no stone in the area suitable for large scale commercial quarrying operations (Stone, pp. 176, 177, 243-245, 1932).

\section{Ceramic Material}

An analysis of shales, apparently Wills Creek or Bloomsburg, obtained near Thompsontown indicates them suitable for the manufacture of brick, hollow tile and drain tile (Leighton, p. 159, 1941). These shales are abundant in Pfoutz Valley and are not far from rail facilities. The Rose Hill shales may also be of value and large amounts could be taken from Slaughterback Hill. Good brick shales might be obtained from the less sandy portions of the Catskill formation. 
The Mavch Chunk formation contains soft red clay shales of good quality for brick manufacture. These shales underlie Hunters Valley and good highway facilities are available just east of the area (Leighton, pp. 158-160, 195-198, 1941).

\section{Ganister}

Vandyke Station, located two miles west of the Millerstown quadrangle along the Pennsylvania Railroad, is the site of an industry utilizing Tuscarora sandstone and subquartzite. Silica brick made from the highly siliceous Tuscarora is used for lining colke ovens and furnaces in metallurgical plants. The sandstone and quartzite is known in the industry as ganister. It is taken from the thick talus deposits on the north flank of Tuscarora Mountain.

That portion of Tuscarora Mountain extending into the Millerstown quadrangle also has large amounts of float suitable for ganister. This rock is present on both flanks of the mountain, but proximity to the raflroad would make the north flank more economical to develop. There is a greater source in bedded Tuscarora under the talus but this will probably not be used in the near future due to higher costs of quarrying (Moore and Taylor, 1924).

\section{Iron Ore}

Iron ore was extensively mined near Millerstown from the early eighteen hundreds until the early nineteen hundreds. Swank (p. 210, 1892) mentions a forge located on Cocolamus Creek south of Millerstown. Known as Mount Vernon forge, it was built in 1804 and abandoned in 1817. The iron supposedly came from a furnace in Mifflin 
County. Later a charcoal furnace was constructed on the north side of the Juniata two miles northwest of Millerstown. Waste material from this furnace may be seen along the present highway. This furnace ceased operation about 1845. Most of the ore came from long slit trenches only a few yards away in slaughterback Hi11.

About 1860 activity increased and a number of shafts and trenches were dug in search for ore, Ore nearest the surface was softer and of higher tenor. Much of the best ore was removed from the trenches. None of the ore was mined to a depth below the level of the Jumiata. The ore was taken largely from the south flanks of Slaughterback Hill and Tuscarora Mountain. Interest at first centered on the beds in Slaughterback HII as the Pennsylvania Canal, which provided the cheap transportation necessary, was located on that side of the river. Later ore was loaded into railroad cars across the river from Millerstown. Ore from as far west as Donnally Mills was carried by horse-drawn wagons to the railroad. Generally only the ore nearest the canal or railroad could be economically worked. The ore was trangported down the river to furnaces in or near Harrisburg.

The ore,which is of sedimentary origin, is found at various horizons within the Rose Hill and Keefer formations. There are a number of highly ferruginous beds known collectively as the Millerstown ore beds, but only three have been sought as an iron ore. The lower two are very siliceous and were never successfully mined. The upper bed is a good grade of soft oolitic hematite but is said to be hard and calcareous where not exposed near the sur- 
face. It is not more than 12 inches thick in the Millerstown area where it contains about $55 \%$ iron (Claypole, pp. 44-51, 93$96,1885)$.

Growth of this industry was cut short by the rapid expansion of the more economical Michigan mining operations. It is doubtful If the Millerstown ore beds will ever again be of economic importance.

\section{Road Material}

A variety of rock has been quarried for use in local road construction. The Marcellus black shales were once quarried and used to cover dirt base roads. These quarry sites or pits are small but numerous along the Marcellus outcrop belt on either side of the Tuscarora anticline. This waterial has no present value as it will not withstand heavy traffic. Its use was due largely to the ease with which it could be quarried.

Oriskany chert has often been used in road construction in the area. A number of quarries were opened, some not many years back, however, none are worked at present. The chert, although very hard, breaks dow readily on weathering and is relatively easy to quarry. The outerop belt of the Oriskany is parallel to and nearby that of the Marcellus formation. This material, like the black shales, is not well suited for heavy truck and automobile traffic. Limestone, which is presently the mott widely used road metal, is abundant in the area. Much of the Tonoloway, Keyser, Helderberg, and Selinsgrove limestone is suitable for crushed stone. Few 
quarries have been opened for this purpose as the beds dip steeply and do not afford large outcrop areas. The most suitable location for large seale quarrying is on the axis of the Blacklog Mountain anticline in the northwest corner of the area. The only limestone quarry now in operation is located at this point one mile north of East Salem. There the Tonoloway limestone is being quarried on the crest of the anticline. The Keyser limestone covers the surface but is badly weathered and much of it cannot be used. The stone is crushed at the quarry site and transported by trucks. The limestone in this quarry is relatively pure, and only a few thin shaly layers can be seen (Figure 10).

A possible quarry site is the synclinal limestone hill west of Delaware Creek and one mile south of East Salem. Neither this site nor the quarry north of East Salem has the advantage of railroad facilities.

Soil

By far the most valuable natural resource of the area is the soil. At present the best farms appear to be those underlain by the middle and upper Silurian shales and limestones. These farms are in Pfoutz Valley and along the slopes of Tuscarora Mountain. Good soil has also formed from the Mauch Chunk formation in Hunters Valley and the Catskill formation which crops out over a large area (See geologic map in appendix). Residual soil of the Portage formation is cultivated although it is a marginal soil. The Hamilton and Marcellus formations produce poor soil, however, it is often cultivated where level. Much of the marginal land cleared many years ago 
has been allowed to revert to timber. The Tuscarora and Pocono formations do not produce a soil suitable for eultivation. The mountains capped by these sandstones are of value only for timber 1and.

The only transported soll of any consequence in the area is found in the western portion near the Juniata. Pleistocene terrace deposits overlie the Silurian sediments in the vieinity of Thompsontown. These deposits form a good soil but must be adequately drained. A plain of recent alluvium two miles east of Thompsontown is cultivated with success but is subject to flooding.

\section{Water}

Water supply has presented no great problems to the residents of the area. Most farms obtain water from shallow dug wells or springs. A few drilled wells are present, and these supply adequate amounts of water for domestic use.

There are three public water supplies in the area. A reservoir supplying the town of Newport is located in Mitchell Gap near the apex of Buffalo and Berry Mountains. This reservoir is filled by runoff from the Pocono capped mountains. A small portion is from springs also in the Pocono formation.

Millerstown is supplied from three springs that issue from a ferruginous sandstone of the Rose Hill formation. The springs are located on the north slope of Tuscarora Mountain, three miles northwest of the town. The springs yield an aggregate of about 38 gallons 
a minute. The water does not require treatment.

Thompsontown receives its water supply from a small surface stream in Turkey Ridge $11 / 2$ miles northeast of the town. During dry summers a spring in the Tonoloway limestone is also used for the public supply. The water is chlorinated before being used. Breyers Ice Cream Co., across the Juniata from Millerstown, uses 300,000 gallons of water a day. This is obtained from springs near the base of Raccoon Ridge.

No flowing wells have been reported but it is highly possible that swch wells could be obtained by deep drilling in the synclinal Hunters Valley (Lohman, pp. 242-250, 258-267, 1938). 


\section{CONCLUSIONS}

It is hoped that information obtained from this study will aid future research within and near the Millerstown quadrangle. The strata cropping out in the area have been described in more detail than in previous reports. The obsolete formation names used in previous reports have been replaced with names now in common usage elsewhere in south-central Pennsylvania.

An areal geologic map has been prepared with a scale of 1:24000 as compared to the existing county maps which have a scale of 1:126,720. The geology has for the first time been placed on a topographic base map. This has made it possible to plot the formation outcrops more accurately.

Although the major folds are indicated on the county geologic maps, a number of anticlines and synclines have been mapped for the first time. Faults not previously reported are also described in this report.

Geologic studies of nearby quadrangles are being conducted by the Pennsylvania Geological Survey. It is recommended that this work be continued so as to obtain a more complete understanding of the processes which have taken place in the geologic history of the area. 


\section{BIBLIOGRAPHY}

Ashley, George H., 1930, Age of the Appalachian Peneplains, Geol. Soc. Am. Bull., vol. 41, pp. 595-700.

1931, A Syllabus of Pennsylvania Geology and Natural Resources, Pennsylvania Geological Survey, Fourth series, Bulletin G-1, Plate I.

1933, Scenery of Pennsylvania, Pennsylvania GeoIogical Survey, Fourth series, Bulletin G-6, pp. 1847, 64-68.

1935, Studies in Appalachian Mountain Sculpture, Geo1. Soc. Am. Bull., vol. 46, pp. 1395-1436.

Brown, Amos P. and Frederick Ehrenfeld, 1913, Mineral of Pennsylvania Topographic and Geological Survey of Pennsylvania Report No. 9.

Butts, Charles, 1945, Geologic Atlas of the United States, Hollidaysburg-Huntington Folio, Pennsylvania, No. 227.

, 1941, Geology of the Appalachian Valley in Virginia, Part II, Fossil Plates and Explanations, Virginia Geological Survey, Bulletin 52.

Claypole, E. W., 1885, A Preliminary Report on the Paleontology of Perry County, Pennsylvania Second Geological Survey, vol. $\mathrm{F}-2$.

Cleaves, A. G., 1937, Oriskany Thicknesses in Pennsylvania, Pennsylvania Academy of Science, vo1. 11, pp. 64-71.

and R. C. Stephenson, 1949, Guidebook to the Geology of the Pennsylvania Turnpike, Carlisle to Irwin, Pennsylvani Geological Survey, Fourth series, Bulletin G-24.

d'Invilliers, E. V., 1891, Report on the Geology of Union, Snyder, Miffiin, and Juniata Counties, Pennsylvania Second Geological Survey, vol. F-3.

Fenneman, Nevin M., 1938, Physiography of Eastern United States, First edition.

Fridley, H. M., 1957 (personal communication) Dept. of Geology, W.V.ษ.

Goddard, E. N., et. al., 1948, Rock Color Chart, The Rock-Color Chart Committee, National Research Counci1, Washington, D.C. 
Johnson, O. W., 1931, Stream Sculpture on the Atlantic Slope.

Lahee, Frederich, 1952, Field Geology, Fifth edition.

Lohman, Stanley W., 1938, Ground Water in South-Central Pennsylvania, Topographic and Geological Survey, Bulletin W-5.

Leighton, Henry, 1934, The White Clays of Pennsylvania, Pennsylvania Geological Survey, Bulletin 112.

1941, Clay and Skale Resources in Pennsylvania, Pennsylvania Geological Survey, Foutth series, Bulletin M-23.

Lesley, J. P., A Summary Description of the Geology of Pennsylvania, Final report, 4 vols., 1892-1895.

Leverett, Erank, 1934, Glacial Deposits in Pennsylvania, Pennsylvania Geological Survey, Fourth series, Bulletin G-7.

Maryland Geological Survey, 1913, Devonian Plates.

Millex, B. LeRoy, 1934, Limestone of Pennsylvania, Pennsylvania Geological Survey, Fourth series, Bulletin M-20.

Miller, John T., Personal communication, Employee of the Pennsylvania Geological Survey.

Moore, E. S., and T. G. Taylor, 1924, The Silica Refractories of Pennsylvania, Pennsylvania Geological Survey, Fourth series, Bulletin M-3.

Norwood, Edward M., 1957, Geology of the Evitts Creek 7 1/2 Minute Topographic Quadrangle, Thesis, West Virginia University.

Peltier, Louic C., 1949, Pleistocene Terraces of the Susquehanna River, Pennsylvania Topographic and Geologic Survey, Bulletin M-3.

Prosser, Charles S., et. al., 1913, Middle and Upper Devonian, Maryland Geological Survey.

Reeside, J. B., 1918, The Helderberg Limestone of Pennsylvania, U.S.G.S., Professional Paper 108, pp. 185=226.

Rogers, Henry D., 1858, Geology of Pennsylvania, vol. I.

Stone, Ralph W., 1932, Building Stones of Pennsylvania, Pennsylvania Geological Survey, Fourth series, Bulletin M-15.

Swank, James M., 1894, History of the Manufacture of Iron Ore in All Ages. 
Swartz, Charles K., 1913, Lower Devonian, Maryland Geological Survey.

\section{Survey.}

Swartz, F. M., and C. K. Swartz, 1931, Early Silurian Formations in South-Eastern Pennsylvania, Geol. Soc. An. Bull., vol. 42, PP. 621-662.

1934, Silurian Sections Near Mount Union, Central Pennsylvania, Geol. Soc. Am. Bu11., vo1. 45, pp. $81-134$.

Twigg, Robert W., 1957, Geology of the Curharland, Maryland 7.5 Minute Topographic Quadrangle, Thesis, West Virgini: University.

Ver Steeg, Kar1, 1930, Wind Gaps and Water Gaps of the Northern Appalachians, etc., New York Academy of Science, vol. 32 .

Von Engeln, O. D., 1942, Geomorphology, 1st edition.

White, I. C., 1883, The Geology of the Susquehanna River Region in the Six Counties, etc., Pennsylvania Second Geological. Survey, vol. G-7.

Willard, Bradford, 1931, Oriskany at Susquehanna Gap, Pennsylvanla, Geol. Soc. Am. Bull., vol. 42, pp. 697-706.

1933, "Catski11" Sedimentation in Pennsylvania, Geol. Soc. Am. Bull., vol. 44, pp. 495-516.

, and A. B. Cleaves, 1933, Hamilton Group of: Eastern Pennsylvania, Geol. Soc. Am. Bull., vol. 44, pp. 757-782.

1935, Hamilton Group of Central Pennsylvania, Geol. Soc. Am. Bul1., vol. 48, pp. 195-224.

1935, Portage Group in Pennsylvania, Geol. Soc. Am. Bu11., vol. 46, pp. 1195-1218.

1936, Onondaga Formation of Pennsylvania, Journal of Geology, vo1. 44, pp. 578-603.

, 1937, Hamilton Correlations, American Journal of Science, Fourth series, vol. 33, pp. 264-278.

, and Arthur B. Cleaves, 1938, A Paleozoic Section in South Central Pennsylvania, Pennsylvania Geological Survey, Fourth series, Bulletin G-8. 
Willard, Bradford, 1939, Highway Geology, Philadelphia to Pittsburgh, Pennsylvaia Geological Survey, Fourth series, Bulletin G-8.

1939, Guide to the Geology from Dauphin to Sunbury, Pennsylvania Geological Survey, Fourth series, Bulletin G-13.

F. M. Swartz, and Arthur B. Cleaves, 1939, The Devonian of Pennsylvania, Pennsylvania Geological Survey, Fourth series, Bulletin G-19.

1939, Ordovician Silurian Relations in Pennsylvania, Geol. Soc. Am. Bu11., vol. 50, pp. 1165-1198.

F. M. Swartz, 1948, Susquehanna and Juniata Valleys, Guidebook of the Fourteenth Annual Field Conference of Pennsylvania Geologists, Excursion 4, Pennsylvania Topographic and Geological Survey.

Wilmarth, M. G., 1938, Lexicon of Geologic Names of the United States, U.S.G.S. Bulletin 896, part I and II.

Woodward, Herbert P., 1941, Silurian System of West Virginia, West Virginia Geological Survey, vol. XIV.

1943, Devonian System of West Virginia, West Virginia Geological Survey, vol. XV.

, 1957, Structural Elements of Northern Appalachians, Bulletin of the American Association Petroleum Geologists, vol. 41, number 7, pp. 1429-1440. 


\section{VITA}

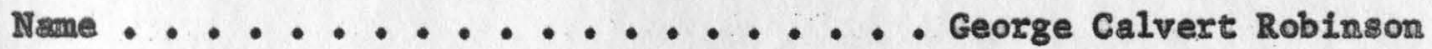

Parents ................ George Graham Robinson Margaret Calvert Robinson

Birthplace ............. Chelyan, West Virginia Date of Birth .................. June 15, 1931

Schools Attended:

Chelyan Elementary School ......... 1937-1943 Chelyan, West Virginia

Chelÿan Junior High Schoo1 . . . . . . 1943-1946 Chelyan, West Virginia

East Bank High Schoo1 . . . . . . . . 1946-1949 East Bank, West Virginia

Marshall College ..... .......... 1949-1953 Huntington, West Virginia

West Virginia Iniversity ........... 1955-1957 Morgantown, West Virginia

Military Service:

United States Army . . . September 1953 - September 1955

Degrees Received: B.S., Geology . . . . . . . . . . . . .
Marshall College

Graduate Work:

West Virginia University . . . . . . . 1955-1957 
APPROVAL OF EXAMINING COMMITIEES

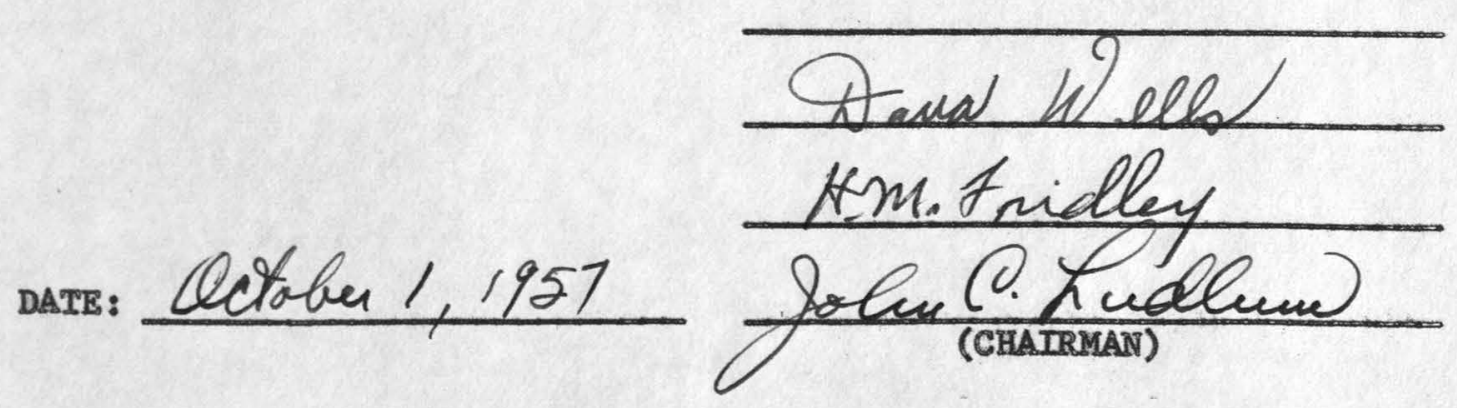

